by Yuanlong Zhao ${ }^{1}$, Jinliang Yuan ${ }^{2}$,Loren E. Babcock ${ }^{3}$, Qingjun Guo ${ }^{4}$, Jin Peng ${ }^{l}$, Leiming Yin ${ }^{2}$, Xinglian Yang ${ }^{l}$, Shanchi Peng ${ }^{2,5 *}$, Chunjiang Wang ${ }^{6}$, Robert R. Gaines ${ }^{7}$, Jorge Esteve ${ }^{8}$, Tongsu Tai ${ }^{9}$, Ruidong Yang ${ }^{l}$, Yue Wang ${ }^{l}$, Haijing Sun ${ }^{2}$, and Yuning Yang ${ }^{l}$

\title{
Global Standard Stratotype-Section and Point (GSSP) for the conterminous base of the Miaolingian Series and Wuliuan Stage (Cambrian) at Balang, Jianhe, Guizhou, China
}

\footnotetext{
${ }^{1}$ College of Resource and Environment Engineering, Guizhou University and Guizhou Research Center for Palaeontology, Guiyang, 550025, China

${ }^{2}$ Nanjing Institute of Geology and Palaeontology, Chinese Academy of Sciences, 39 East Beijing Road, Nanjing 210008, China

${ }^{3}$ School of Earth Sciences, The Ohio State University, 125 South Oval Mall, Columbus, OH 43210, USA

${ }^{4}$ Center for Environmental Remediation, Institute of Geographic Sciences and Natural Resources Research, Chinese Academy of Sciences, Beijing 100101, China

${ }^{5}$ State Key Laboratory of Paleobiology and Stratigraphy, Chinese Academy of Sciences, Nanjing 210008, China; *Corresponding author, E-mail: scpeng@nigpas.ac.cn

${ }^{6}$ College of Geosciences \& State Key Laboratory of Petroleum Resources and Prospecting, China University of Petroleum, Beijing 102249, China ${ }^{7}$ Geology Department, Pomona College, 185E. Sixth Street, Claremont, CA 91711, USA

${ }^{8}$ Departamento de Paleontolgía, Facultad de CC Geológicas, Universidad Complutense de Madrid, José Antonio Novais 12, 28040, Madrid, Spain

${ }^{9}$ Agency of Kaili Area Protected Fossils, Jianhe, Guizhou 556300, China
}

(Received: December 17, 2018; Revised accepted: May 20, 2019)

https://doi.org/10.18814/epiiugs/2019/019013

The International Commission on Stratigraphy and the IUGS Executive Committee have recently ratified a Global Standard Stratotype-section and Point (GSSP) defining the conterminous base of the third series and the fifth stage of the Cambrian System. The series and the stage are respectively named the Miaolingian Series and Wuliuan Stage, after the Maioling Mountains in southeastern Guizhou and the Wuliu sidehill, Jianhe County, in eastern Guizhou Province, South China, where the GSSP is located. The GSSP is exposed in a natural outcrop near the Balang Village at a position of $26^{\circ} 44.843^{\prime} \mathrm{N}$ latitude and $108^{\circ} 24.830^{\prime} \mathrm{E}$ longitude. It is defined at the base of a silty mudstone layer $52.8 m$ above the base of the Kaili Formation in the WuliuZengjiayan section, coinciding with the first appearance of the cosmopolitan oryctocephalid trilobite Oryctocephalus indicus (base of the O. indicus Zone). Secondary global markers at or near the base of the series and stage include the peak of a rather large negative carbon isotopic excursion (ROECE excursion), the simultaneous appearance of many acanthomorphic acritarch forms, a transgressive phase of a major eustatic event, and the last appearance of intercontinental polymerid trilobites, either Bathynotus or Ovatoryctocara. Faunal turnovers close to the base of the Miaolingian Series and Wuliuan Stage have been recognized as being at the base of the Oryctocephalus indicus Zone of Amgan Stage in Siberia, the Delamaran Stage in
Laurentia, the Oryctocephalus indicus Zone in the Indian Himalaya and North Greenland, near the base of the Delamaran Stage in Australia, and within the Eccaparadocides sdzuyi Zone in Iberia and the Ornamentaspis frequens Zone in Morocco.

\section{Introduction}

The International Subcommission on Cambrian Stratigraphy (ISCS) has recommended a subdivision of the Cambrian System into four series (Peng, 2004, 2006; Babcock et al., 2005; Peng et al., 2006; Babcock and Peng, 2007). Within each series it is expected that two or three stages will be recognized with their boundaries corresponding to horizons that can be precisely correlated with confidence through almost all palaeocontinents. Cambrian boundary positions ratified by the International Union of Geological Sciences (IUGS) and International Commission on Stratigraphy (ICS) (Figs. 1,2) are: 1, the base of the Terreneuvian Series and Fortunian Stage, which is also the base of Cambrian System, Paleozoic Erathem and Phanerozoic Eonothern, corresponding to the base of Treptichnus pedum Zone in Newfoundland (Brasier et al., 1994; Landing, 1994; Gehling et al., 2001; Landing et al., 2007); 2, the base of Drumian Stage corresponding to the base of the Ptychagnostus atavus Zone in Utah, USA (Babcock et al., 2007); 3, the base of the Guzhangian Stage corresponding to the base of Lejopyge laevigata Zone in Hunan, South China (Peng et al., 2009a); 4, the base of the Furongian Series and Paibian Stage corre- 


\begin{tabular}{|c|c|c|c|}
\hline SYSTEMS & SERIES & STAGES & $\begin{array}{l}\text { Boundary horizons (GSSPs) or } \\
\text { provisional stratigraphic tie points }\end{array}$ \\
\hline Ordovician & Lower & Tremadocian & \multirow{5}{*}{$\begin{array}{l}\text { FAD of lapetognathus fluctivagus (GSSP) } \\
\text { FAD of Lotagnostus americanus } \\
\text { FAD of Agnostotes orientalis (GSSP) } \\
\text { FAD of Glyptagnostus reticulatus (GSSP) }\end{array}$} \\
\hline \multirow{10}{*}{$\frac{z}{2}$} & \multirow{3}{*}{ Furongian } & $\begin{array}{c}\text { Cambrian Stage } 10 \\
\text { (Undefined) }\end{array}$ & \\
\hline & & Jiangshanian & \\
\hline & & Paibian & \\
\hline & \multirow{3}{*}{ Miaolingian } & Guzhangian & \\
\hline & & Drumian & \multirow{2}{*}{$\begin{array}{l}\text { FAD of Lejopyge laevigata (GSSP) } \\
\text { FAD of Ptychagnostus atavus (GSSP) }\end{array}$} \\
\hline & & Wuliuan & \\
\hline & \multirow{2}{*}{$\begin{array}{l}\text { Cambrian } \\
\text { Series } 2 \\
\text { (Undefined) }\end{array}$} & $\begin{array}{c}\text { Cambrian Stage } 4 \\
\text { (Undefined) }\end{array}$ & \multirow{2}{*}{$\begin{array}{l}\text { FAD of Oryctocephalus indicus GSSP position } \\
\text { ?FAD of Olenellus or Redlichia }\end{array}$} \\
\hline & & $\begin{array}{l}\text { Cambrian Stage } 3 \\
\text { (Undefined) }\end{array}$ & \\
\hline & \multirow{2}{*}{ Terreneuvian } & $\begin{array}{l}\text { Cambrian Stage } 2 \\
\text { (Undefined) }\end{array}$ & \multirow{2}{*}{$\begin{array}{l}\text { ?FAD of trilobites } \\
\text { FAD of Watsonella crosbyil } \\
\text { FAD of Aldanella attleborensis }\end{array}$} \\
\hline & & Fortunian & \\
\hline Ediacaran & & & FAD of Trichophycus pedum (GSSP) \\
\hline
\end{tabular}

Figure 1. Chart showing working model for global chronostratigraphic subdivision of the Cambrian System, indicating the lower boundary of the newly ratified Miaolingian Series and Wuliuan Stage (modified from Peng et al., 2009a, 2012b).

sponding to the base of Glyptagnostus reticulatus Zone in Hunan, South China (Peng et al., 2004a); 5, the base of the Jiangshanian Stage corresponding to the base of the Agnostotes orientalis Zone in Zheji- ang, Southeast China (Peng et al., 2012a); and 6 , the base of Miaolingian Series and Wuliuan Stage, ratified recently, in Southwest China.

The purpose of this paper is to announce ratification of the GSSP for the conterminous base of the Miaolingian Series and the Wuliuan Stage, which coincides with the FAD of the intercontinental oryctocephalid trilobite Oryctocephalus indicus. The Miaolingian Series and the Wuliuan Stage are newly named Cambrian chronostratigraphic units, replacing in concept and content the provisional Series 3 and Stage 5 (Figs. 1, 2, 5, 7, 9). The GSSP for the base of the new series and new stage lies within Bed 9 at $52.8 \mathrm{~m}$ above the base of the Kaili Formation in the Wuliu-Zengjiayan section that is about $0.5 \mathrm{~km}$ North of Balang Village, Jianhe County, eastern Guizhou Province, South China (Figs. 3, 4). This point fulfills all of the geological and biostratigraphic requirements for a GSSP (see Remane et al., 1996). The section is easily accessible, and access for research is unrestricted. It is located within the Jianhe Natural Reserve of Paleontological Fossils and the Miaoling National Geopark, both have been under permanent protection by the government of Guizhou Province since the natural reserve was approved in 2002 and by the Ministry of Land and Mineral Resources of China since the geopark was approved in 2009.

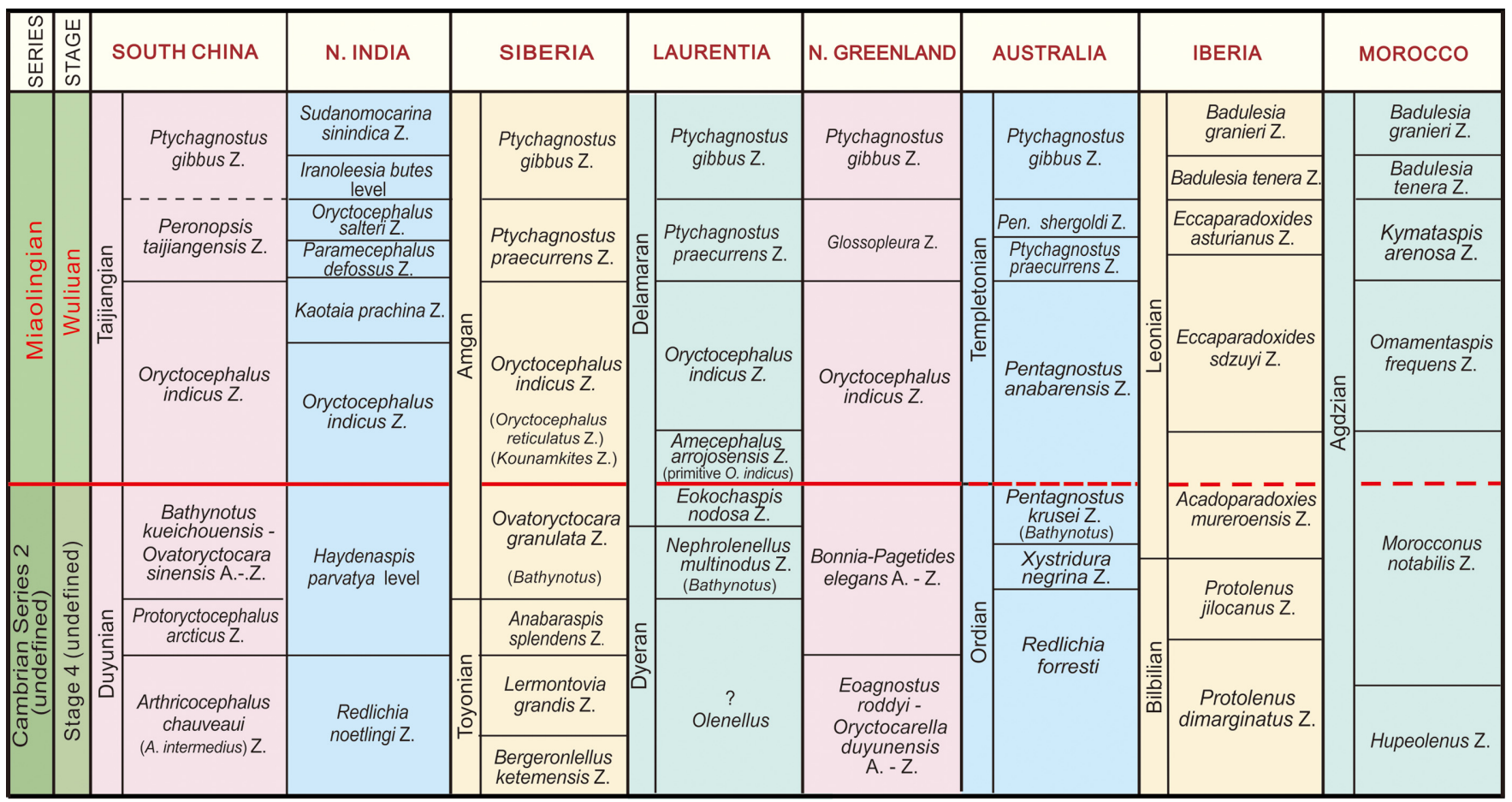

Figure 2. Correlation chart of the interval of Cambrian Stage 4 through Wuliuan Stage (Miaolingian Series). Chart compiled from numerous sources, summarized principally in Yuan and Ng. (2014), Geyer (2015), Zhao et al. (2015, 2017), Hughes (2016), Sundberg et al. (2016), Peng et al. (2017) and Esteve et al. (2017). 


\section{Stratigraphic Rank of the Boundary}

The Miaolingian Series is the third series of the Cambrian System, and the Wuliuan Stage is the lowermost stage of the Miaolingian
Series (Figs. 1, 2). The base of the series and stage defines automatically the top of provisional Cambrian Series 2 and its uppermost stage, the provisional Stage 4, both of which are unnamed yet. The boundary will be a standard series/epoch and stage/age GSSP. The upper boundary of the series is defined by the base of the Furongian Series, and the
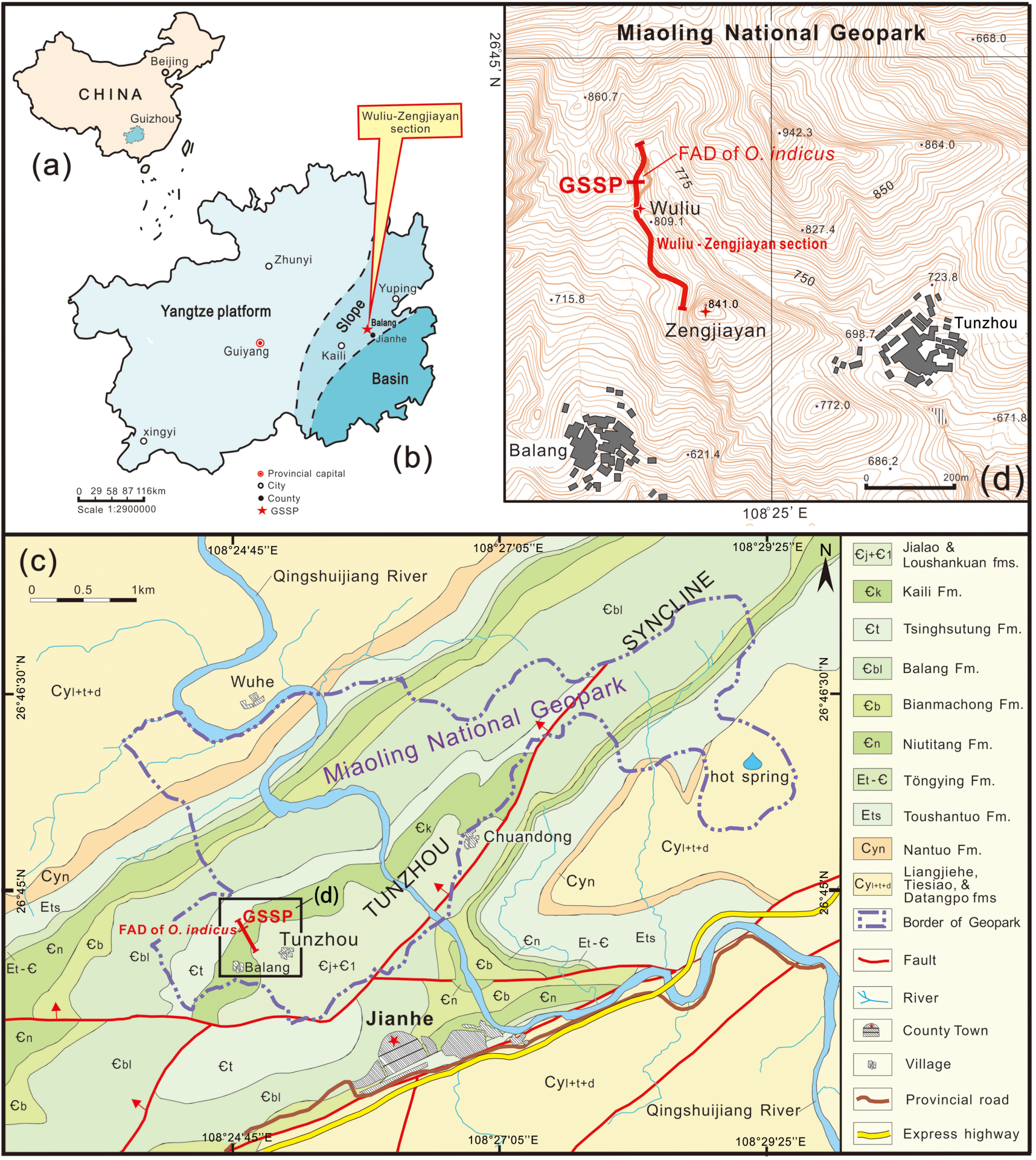

Figure 3. (a) Location of Guizhou in China (outlined blue area); (b) Cambrian palaeogeography of Guizhou with the Wuliu-Zengjiayan GSSP section indicated by a red star; (c) Geological map of the part of eastern Guizhou province, showing the study area and the location of the GSSP section for the Miaolingian Series and Wuliuan Stage (modified from Geological Survey of Guizhou Province, 1966); (d) Topographic map of the Balang and Tunzhou area, indicating location of the Wuliu-Zengjiayan GSSP section with the FAD of Oryctocephalus indicus (red line; modified from topographic map G-49-37-55, Dagaowu Sheet, issued by Surveying and Mapping Bureaus of Guizhou and Shaanxi, 1991; 1:10000 sale); the Wuliu-Zengjiayan section is named after the Wuliu sidehill and Zengiiayan hill (indicted by red stars). 
upper boundary of the stage is defined by the base of the Drumian Stage of the Miaolingian Series (Fig. 1).

The names Wuliuan and Miaolingian are derived from geographic localities in eastern, where the GSSP is located, and southeastern Guizhou. The name of Wuliuan Stage (and Age) is derived from Wuliu, a sidehill that the Wuliu-Zengjiayan section crosses, and the name Miaolingian Series (and Epoch) is derived from the Miaoling Mountains, which traverse the southeastern part of the Guizhou Province. These mountains are inhabited primarily by the Miao ethnic minority.

\section{Geography and Physical geology of the GSSP}

\section{Geographic Location}

The Wuliu-Zengjiayan section (Yuan et al., 1997, 1999, 2002; Zhao et al., 2001a, b, 2004, 2007; 2012a, c) is exposed along a hill ridge, which is about $0.5 \mathrm{~km}$ northeast of Balang Village, Jianhe County (formerly the village was administered by Taijiang County), Guizhou Province, China (Fig. 3). The studied area lies in the southwest of the Miaoling National Geopark (Fig. 3(c)). The Balang Village is located $2.5 \mathrm{~km}$ from the township of Jianhe County, which is easily accessible via the Guiyang-Kaili-Yuping Express Highway. The position of the WuliuZengjiayan section is on topographic map G-49-37-55, Dagaowu Sheet, 1:10000 sale (Fig. 3(d)). The GSSP is exposed near the ridge crest at a position of $26^{\circ} 44.843^{\prime} \mathrm{N}$ latitude and $108^{\circ} 24.830^{\prime} \mathrm{E}$ longitude at an elevation of approximately $795 \mathrm{~m}$.

\section{Geological Location}

The Cambrian geology of eastern Guizhou, the site of the GSSP section, has been summarized in a number of papers, among which the most notable are the monographs on the Regional Geology of Guizhou Province published by the Guizhou Bureau of Geology and Mineral Resources (1987), and articles by Yin (1987), Yuan et al. (2002), and Zhao et al. (2011).

The Miaoling Mountains in southeastern Guizhou consist of a series of folds and thrust slices resulting from post-Devonian compressional tectonics that affected the area between the Duliujiang and Qingshuijiang river system of eastern Guizhou (Yin, 1987). The Balang area of Jianhe County, eastern Guizhou, is located on the northwestern limb of the Tunzhou Syncline (Fig. 3(c)), which belongs to the Shansui Composite Syncline in the Nanhua fold belt. The lower half of the Cambrian System in this area was deposited on the lower part of the Jiangnan Slope (mostly shale facies), which was located between the Yangtze carbonate platform to the northwest and deeper water facies of the Jiangnan Basin to the southeast (e.g., Yin, 1987; Peng and Babcock, 2001) (Fig. 3(b)). Exposure of Neoproterozoic and Cambrian strata in the Jianhe area is highly favorable. The Precambrian succession there consists of several formations, which, in ascending order, are the Liangjiehe, Tiesiao, Datangpo, Nantuo, Toushantuo (=Doushantuo), and Töngying (=Dengying) formations (the former three units are marked as $\mathrm{Cy}_{\mathrm{lt+t}}$ on Fig. 3(c)). The Cambrian succession in this area comprises seven units. In ascending order these are the Niutitang, Bianmachong, Balang, Tsinghsutung, Kaili, Jialao and Loushankuan (=Loushanguan) formations (Fig. 3(c)). Detailed descriptions of these units have been presented in a number of papers (Zhou et al., 1980; Yin, 1987; Pu and Ye, 1991; Zhao et al., 2001a, b). An overview of Cambrian paleogeography, biotic provinces, and geologic history of the region was provided by Peng and Babcock (2001).

The Kaili Formation is exposed widely in eastern and southeastern Guizhou, showing a SW-NE trend across the Danzhai, Taijiang, Jianhe, Zhenyuan and Yuping counties to the Tongren area. The Kaili Formation was deposited in an open-shelf to slope setting (Zhou et al., 1980; Zhang et al., 1996; Zhao et al., 2001a, b; Yuan et al., 2002; Gaines et al., 2011), where it overlies either the Wuxun Formation or the Tsinghsutung Formation and is overlain by the Jialao Formation (Figs. 4(a), 5). The formation is typically about $250 \mathrm{~m}$ thick, and straddles the boundary of the provisional Cambrian Series 2 and the Miaolingian Series. The Kaili Formation crops out extensively in the Balang and Chuandong areas (Fig. 3(c)), where it overlies the Tsinghsutung Formation in conformity. The Wuliu-Zengjiayan section contains strata extending from the top part of the Tsinghsutung Formation to the basal part of the Jialao Formation with the GSSP occurring in the lower part of the Kaili Formation. The Kaili Formation contains a total of 47 trilobite genera (subgenera) with 16 genera occurring below the GSSP level, 20 genera above, and 11 genera ranging through the boundary (Zhao et al., 2001a, b; Yuan et al., 2002). Trilobites are commonly articulated and thin shelled, indicating a relatively deep, quiet water sedimentary environment (Zhang et al., 1996; Zhu et al., 1999; Yuan et al., 2002; Gaines et al., 2011).

\section{Location of Level and Specific Point}

The boundary interval of the Wuliu-Zengjiayan section consists primarily of silty and calcareous mudstones (Fig. 5) that are abundantly fossiliferous and bear the first appearance datum (FAD) of the widely distributed oryctocephalid trilobite Oryctocephalus indicus (Fig. 6(a)-(d)), which is selected as primary marker to define the provisional Stage 5 of Cambrian by the International Subcommission on Cambrian Stratigraphy, at $52.8 \mathrm{~m}$ above the base of the Kaili Formation (Zhao et al., 2001a, b). The species $O$. indicus is associated with a large number of trilobites, such as Pagetia, Euarthricocephalus, Burlingia and Olenoides. Below GSSP level, the Bathynotus kueichouensis-Ovatoryctocara sinensis Assemblage-Zone is recognized (Figs. 4(a), 5, 6), which is characterized by the presence of many trilobites with broad geographic ranges, e.g. Bathynotus, Redlichia, Oryctocephalops, Ovatoryctocara, and Oryctocephalites (Yuan et al., 1997, 2002; Zhao et al., 2001a, b, 2007, 2012a, c; Sundberg et al., 2011; Fig. 6(e)-(h)).

\section{Stratigraphic Completeness}

Detailed bed-by-bed correlation of the Miaolingian strata through eastern Guizhou, coupled with detailed biostratigraphy (Yuan et al., 1997, 1999, 2002; Yin and Yang, 1999; Yang and Yin, 2001; Zhao et al., 2001a, b, 2004, 2005, 2007, 2012a, b, c, 2014, 2015, 2017; Yin et al., 2010; Sundberg et al., 2010, 2011), sedimentology (Zhang et al., 1996; Gaines et al., 2011), carbon isotope chemostratigraphy (Yang et al., 2003; Guo et al., 2005, 2010a, b), sulphur isotope chemostratigraphy (Guo et al., 2014) and biomarkers (Wang et al., 2014) clearly demonstrate the stratigraphic continuity of the basal interval of the Wuliuan 

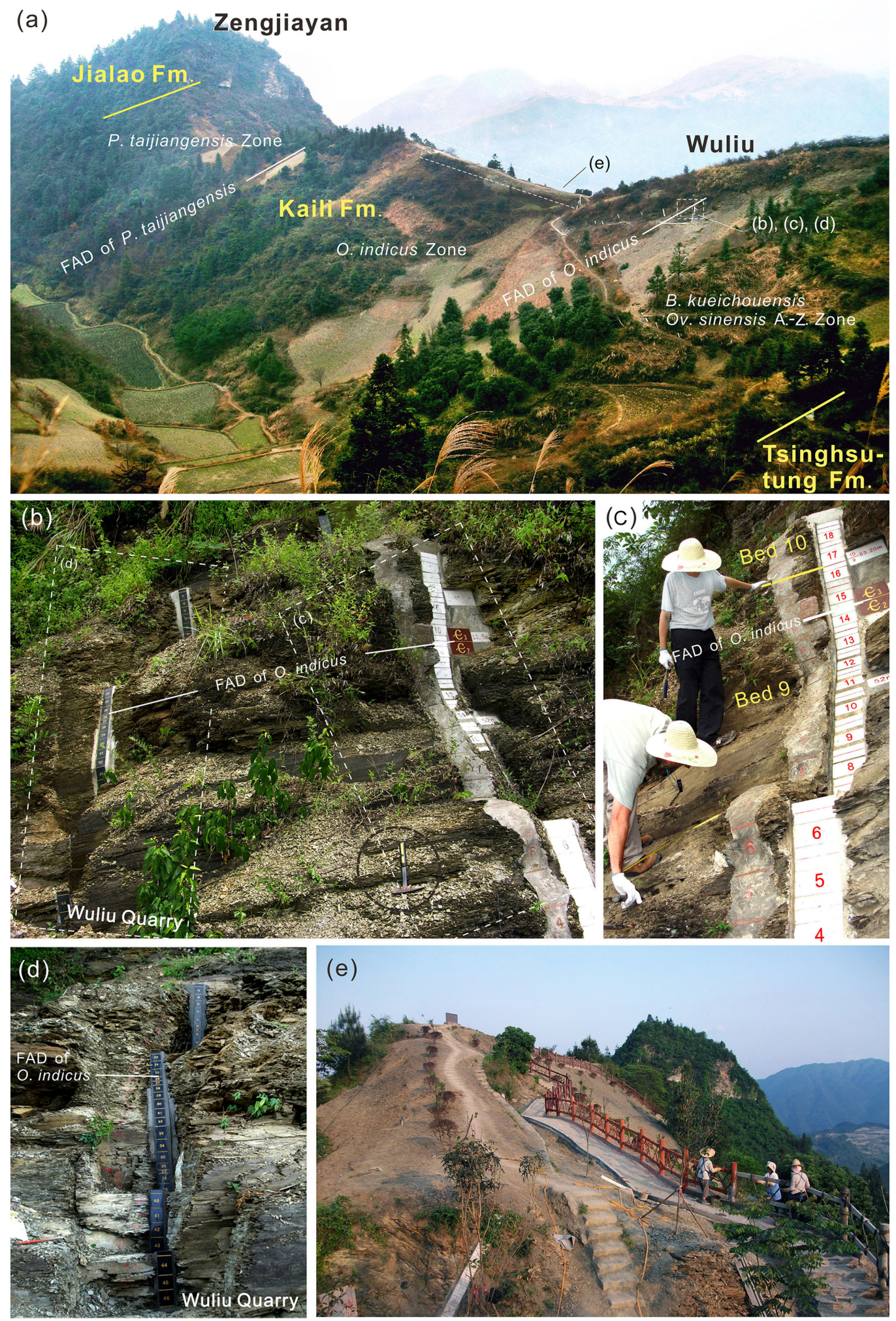

Figure 4. Exposure of the Wuliu-Zengjiayan GSSP for the base of the Wuliuan Stage (coinciding with the FAD of Oryctocephalus indicus in the Kaili Formation?near Balang, Jianhe County, Guizhou Province, South China. Strata underlying the Wuliuan GSSP belong to the upper part of undefined Cambrian Stage 4 of provisional Series 2. (a) View of the Wuliu-Zengjiayan section showing three trilobites zones of the Kaili Formation; (b) The boundary interval of the GSSP in Wuli-Zengjiayan section, showing the FAD of O. indicus in the lower part of the Kaili Formation; (c) and (d) close-up views of the rectangle areas in (b). (c) Showing the bed numbers in yellow (Bed 9 and 10), the numbers of collecting interval in red on the white marble, and the FAD of $O$. indicus, which lies at $52.8 \mathrm{~m}$ above the Kaili Formation and defines the base of Wuliuan Stage; (d) The "Wuliu Quarry", studied by Sundberg et al. (2011), with identical succession and fossil ranges as the WuliuZengjiayan GSSP section; (e) Partial outcrop of the O. indicus Zone, where the rocks yield the Kaili Biota, along with a walk terrace leading to the GSSP site. 
Stage (Miaolingian Series) in the Wuliu-Zengjiayan section. Biostratigraphic studies of eastern Guizhou and other countries have revealed a consistent succession of trilobite species and acritarch taxa (e.g., Tchernysheva, 1962; Zhang et al., 1980; Whittington, 1988, 1995; Astashkin et al., 1991; Moczydłowska, 1991; Palmer and Repina, 1993; Jell and Hughes, 1997; Yuan et al., 1997, 2002; Sundberg and McCollum, 1997, 2003; Palmer, 1998; Hughes and Jell, 1999; Yin and Yang, 1999;
Sundberg et al., 1999, 2011; Shergold and Whittington, 2000; Yang and Yin, 2001; Korovnikov, 2001, 2006; Zhao et al., 2001a, b, 2004, 2007, 2012a, b, 2014, 2015; Geyer, 2005; Fletcher, 2007; McCollum and Sundberg, 2007; Shabanov et al., 2008; Kruse et al., 2009; Peng et al., 2009b; Yin et al., 2009, 2010; Moczydłowska and Yin, 2012; Hughes, 2016; Singh et al., 2016; Sundberg et al., 2016) as observed in the WuliuZengjiayan section. This section is interpreted to represent continu-

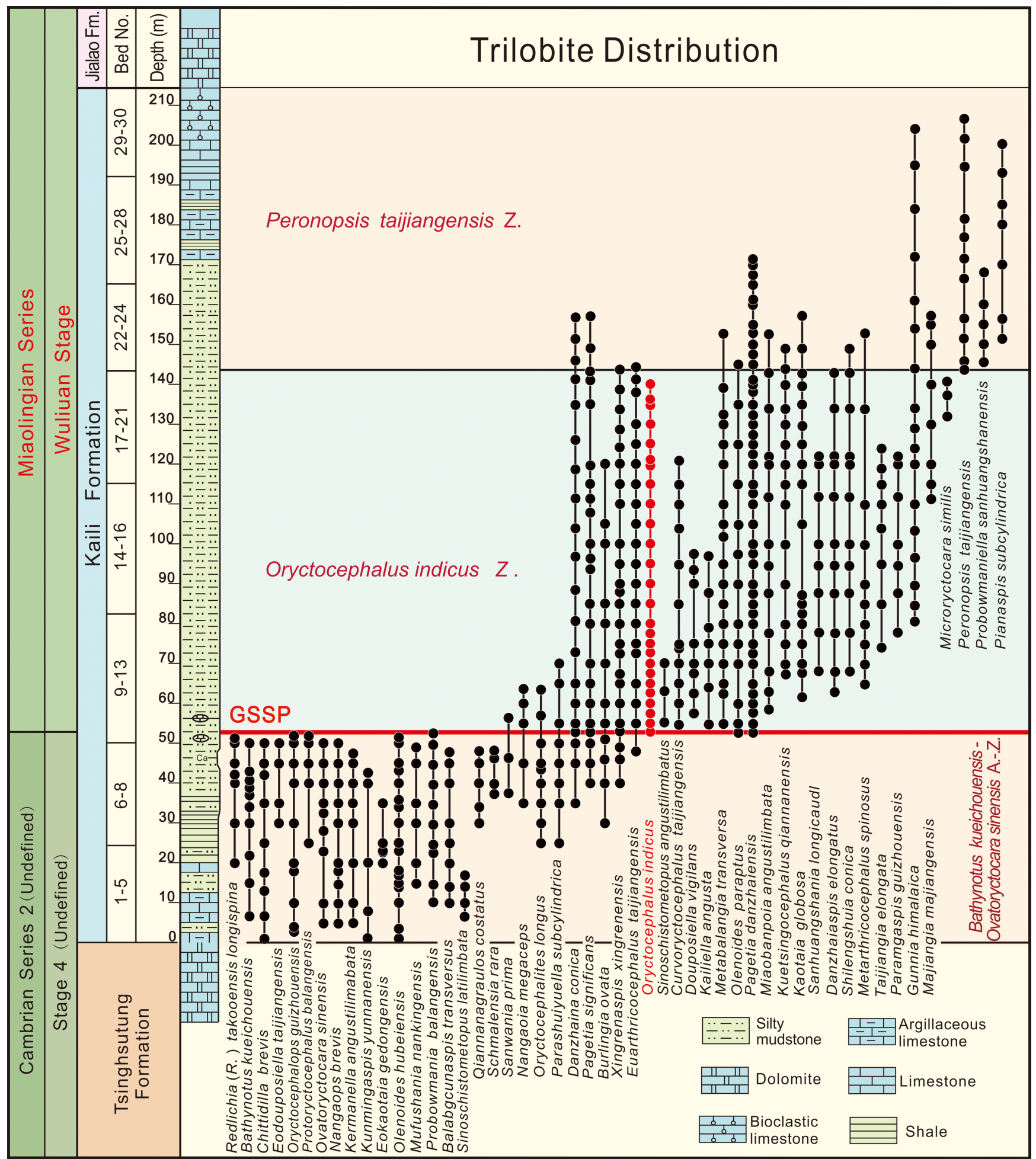

Figure 5. Observed stratigraphic distribution of trilobites in the Wuliu-Zengjiayan section near Balang, Jianhe, Guizhou, South China. The GSSP coincides with the base of the Oryctocephalus indicus Zone in this section, lying $52.8 \mathrm{~m}$ above the base of the Kaili Formation. 
ous deposition of a succession of shales and subordinate lime mudstones across the GSSP boundary interval (Zhang et al., 1996; Yuan et al., 2002; Zhao et al., 2005, 2007, 2012a, c; Sundberg et al., 2010, 2011; Gaines et al., 2011). The section lacks generally syndepositional and tectonic disturbance at the GSSP boundary interval, although small scale folding or minor bedding-plane slippage occurs along some beds and more or less tectonic shearing happened to fossil specimens, which are expected in an inclined succession of fine-clastic strata. Bedding-plane slip surfaces do not appear to have resulted in any loss or repetition of stratigraphic thickness, and event-driven deposition was maintained across the Kaili Formation with no evidence for condensation (Gaines et al., 2011). In addition, the biostratigraphic succession in the section is consistent with numerous reference sections in the region (Zhao et al., 2001a, b, 2007; Fig. 5). Although the section has been affected by mild oxidative weathering, no evidence of significant diagenetic alteration or metamorphism is present.

\section{Thickness and Stratigraphic Extent}

The Kaili Formation is $214.2 \mathrm{~m}$ thick at the Wuliu-Zengjiayan section (Zhao et al., 2001a, b, 2007, 2012a, c; Yuan et al., 2002). Lithologically, the formation is subdivided into three units: the lower part is composed of thin-bedded limestones with silty mudstone interbeds, with a thickness of $23.7 \mathrm{~m}$ (Bed 1-5); the middle part, including the Oryctocephalus indicus Zone and the well-known Kaili Biota-bearing interval (Zhao et al., 2005, 2011), is $150.43 \mathrm{~m}$ thick (Bed 6-27) and is dominated by silty mudstones, mudstone, calcareous mudstone, and shale layers, containing carbonate lenticles in the lower portion; the upper part, including most of the Peronopsis taijiangensis Zone, consists of thin-bedded limestone layers and intercalated shale, grading into grainy limestone and bioclastic limestone with a thickness of $40.07 \mathrm{~m}$ (Bed 28-30; Fig. 5).

The GSSP for the base of the Miaolingian Series and the Wuliuan Stage occurs in a succession composed of greenish-grey, internally laminated silty mudstone in the mid-lower part of the Kaili Formation (Figs. 4(b)-(d), 5). The strata below the GSSP belong to the upper part of undefined Cambrian Stage 4 or to the Duyunian Stage in the terminology used for South China.

\section{Provisions for Conservation, Protection, and Accessibility}

The exposure containing the GSSP in the Balang area has received permanent protection, due to the geological significance, from the government of Guizhou since 2002, when the Balang area was approved as Jianhe Natural Reserve of Paleontological Fossils. In 2009, this area was included as a part of the Miaoling National Geopark and since then has been managed and protected by both governments of Guizhou Province and Jianhe County.

Access to the outcrop is essentially unrestricted in all seasons. Travel to Guizhou is open to persons of all nationalities, and travel for scientific purposes is always welcomed. Ordinary vehicles can be driven from the Jianhe Township directly to Balang or Tunzhou village in no more than 20 minutes. From either village, the GSSP is easily reached by $20-30$ minute walking via paved paths.

\section{Motivation for Selection of the Boundary Level and of the Potential Stratotype Section}

\section{Principal Correlation Event (marker) at GSSP Level}

The oryctocephalid trilobite Oryctocephalus indicus (Reed, 1910) (Fig. 6(a)-(d)) has an intercontinental distribution and its first appearance has been acknowledged as one of the most favorable level for the GSSP defining the base of a global stage (e.g. Jell and Hughes, 1997; Yuan et al., 1997; Hughes and Jell, 1999; Sundberg et al., 1999, 2010, 2011, 2016; Geyer and Shergold, 2000; Korovnikov, 2001, 2006; Peng and Babcock, 2001; Shergold and Geyer, 2001, 2003; Zhao et al., 2001a, b, 2004, 2006, 2007, 2012a, b, c, 2014, 2017; Yuan et al., 2002; Peng, 2003; Sundberg and McCollum, 2003; Babcock et al., 2005, 2014; McCollum and Sundberg, 2005, 2007; Peng et al., 2006, 2012b; Geyer and Peel, 2011; Hughes, 2016; Singh et al., 2016; Esteve et al., 2017; Zhao et al., 2017). Besides South China, the species has been identified from northern India (Indian Himalaya) (Reed, 1910; Jell and Hughes, 1997; Peng et al., 2009b; Hughes, 2016; Singh et al., 2016), western USA (Sundberg and McCollum, 1997, 2003), North Greenland (Geyer and Peel, 2011), North Korea (Saito, 1934), and more possibly from Siberia (Korovnikov, 2001, 2006; Zhao et al., 2006; Fletcher, 2007; Shabanov et al., 2008; Hughes, 2016; Esteve et al., 2017).

Oryctocephalus indicus provides the best and most precise tool for intercontinental correlation in the lower part of Cambrian Series 3 (Zhao et al., 2001a, b, 2012a, b, c, 2014; Yuan et al., 2002; Sundberg et al., 2010, 2011, 2016; Geyer and Peel, 2011; Yuan and Ng, 2014; Hughes, 2016). Some widely distributed trilobites in the $O$. indicus Zone also provide fine tools for intercontinental correlation.

The primitive form of Oryctocephalus indicus makes its first appearance in the lower-middle part of the Kaili Formation in the Balang-Chuandong area, Jianhe County, Guizhou Province. Specimens of $O$. indicus with the primitive morphology possess only two pairs of marginal spines on the pygidium. These forms are succeeded and replaced by the advanced morphotype, characterized by three pairs of pygidial marginal spines (Yuan et al., 2002). The advanced form of $O$. indicus occurs in the $O$. indicus Zone of Nevada and California, USA (Sundberg and McCollum, 1997, p. 1075), and the interval of its occurrence can be correlated with the middle-upper part of the $O$. indicus Zone of South China. Oryictocephalus americanus from the Amecephalus arrojosensis Zone in Nevada, USA (Sundberg and McCollum, 2003), also shows the primitive feature of $O$. indicus. Specimens assigned to $O$. americanus lack connected transglabellar furrows (S2, S3), apparently as a result of taphonomic bias. Sundberg (personal communication, 2008) suggested that it gave rise to the advanced form of $O$. indicus but Zhao et al. $(2006,2007)$ and Esteve et al. (2017) preferred to regard it as a junior synonym of $O$. indicus. The FAD of $O$. indicus always succeeds the disappearance of Olenellus in Laurentia and Redlichia in the Indo-Pacific faunal province, allowing precise correlation among these levels in different faunal realms.

Stratigraphically, the first appearance of the primitive form of Oryctocephalus indicus at the Wuliu-Zengjiayan section lies $1.2 \mathrm{~m}$ above the LAD of the redlichiid trilobite Bathynotus and $0.2 \mathrm{~m}$ above the LAD of Redlichia (Sundberg et al., 2011). In the western United States, the first appearance of $O$. indicus $(=O$. americanus) succeeds 

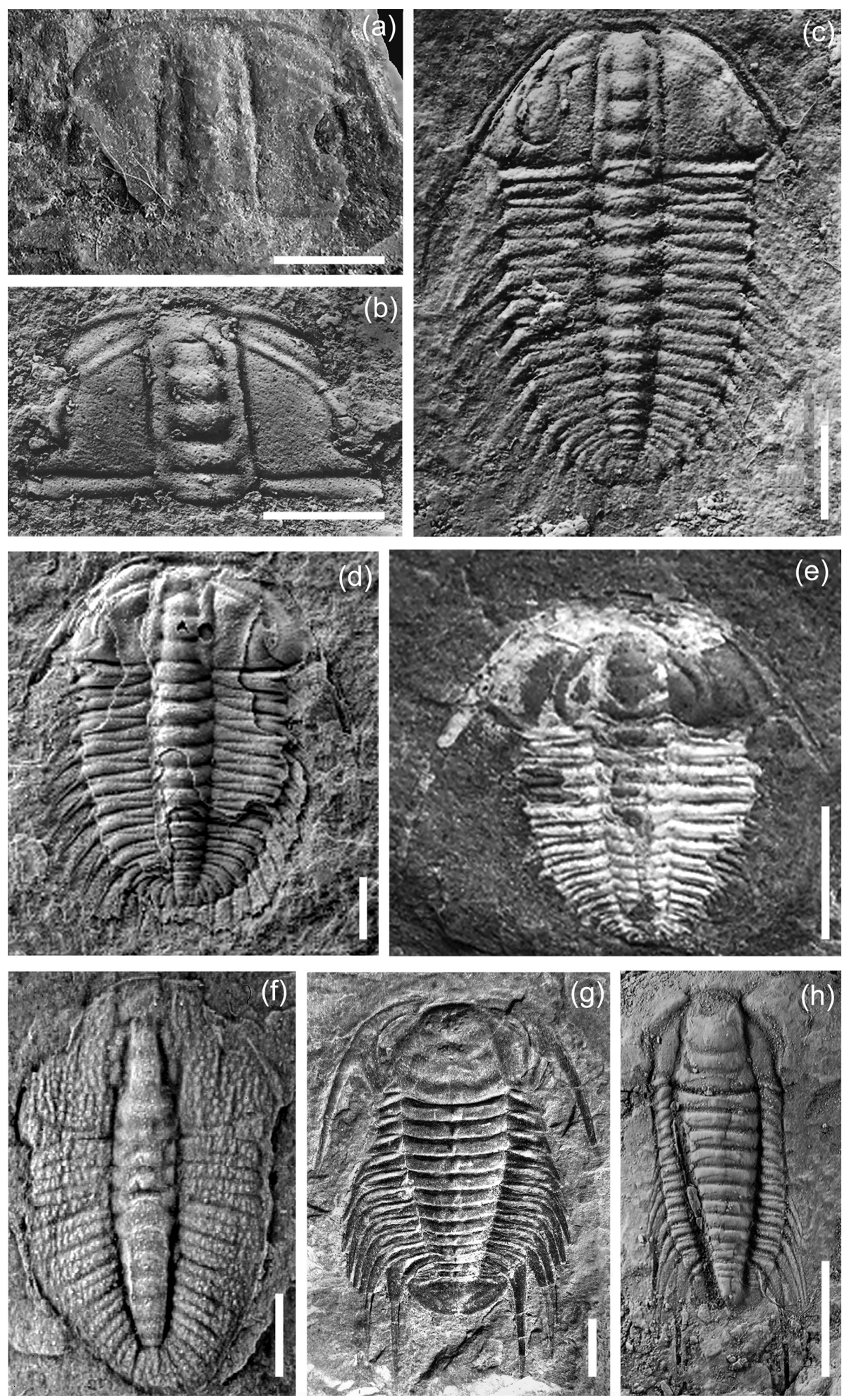

Figure 6. Key trilobite species used for recognition of the base of the Miaolingian Series and Wuliuan Stage. All specimens were collected from the Kaili Formation of the Wuliu-Zengjiayan section; all are dorsal views, collecting horizons are in meters above the base of the formation, (a)-(d) Oryctocephalus indicus (Reed, 1910). (a) cranidium, GTBB1-15-19a, $52.8 \mathrm{~m}$ (first appearance datum); (b) Cranidium, GTB17-5-119, 120.80 m; (c) Exoskeleton, GTB 20-5-1554, $135.70 \mathrm{~m}$; (d) Exoskeleton, GTB 11-111, $56.70 \mathrm{~m}$; (e) Redlichia (R.) takooensis longispina Guo and Zhao, 1998, exoskeleton, GTBB1-3-3, $49.4 \mathrm{~m}$; (f) Ovatoryctocara sinensis Zhao, Yuan, Peng, Yang et Esteve, 2015, exoskeleton, GTBFZK-42, $51.8 \mathrm{~m}$; (g)-(h), Bathynotus kuichouensis Lu in Wang et al., 1964. (g) Exoskeleton, GTB6-3-25, 25.9 m; (h) Exoskeleton, GTBB1-47-1, $40.6 \mathrm{~m}$. Scale bars $=1 \mathrm{~mm}$ for figs. (a) -(b), $2 \mathrm{~mm}$ for figs. (c) -(f), $5 \mathrm{~mm}$ for figs. (g)-(h). the disappearance of Olenellus. The combination of the FAD of $O$. indicus, the narrow stratigraphic range of $O$. indicus, the stratigraphically abrupt disappearance of redlichiids and olenellid trilobites, and evolutionary advances in oryctocephalids and ptychopariids allows the base of the Wuliuan Stage to be tightly constrained. Bathynotus, which occurs at the top of Cambrian Stage 4, is a guide fossil found in the western United States, Siberia, Australia and South China (Webster, 2009; Peng et al., 2014). Its distribution overlaps that of Olenellus and Redlichia, and this taxon has been treated as the most effective secondary tool for intercontinental correlation.

As discussed previously (Babcock et al., 2004, 2007; Peng et al., 2004b, 2006), the selection of a GSSP in open-shelf to slope deposits, and particularly in one from a lowlatitude region such as the South China Platform, is desirable. Slope settings of the Cambrian favored a combination of cosmopolitan trilobites including agnostoids, oryctocephalids and polymerids, such as Pagetia significans, Euarthricocephalus and Curvoryctocephalus in the Oryctocephalus indicus Zone, Bathynotus, Ovatoryctocara and Redlichia in the Bathynotus kueichouensis-Ovatoryctocara sinensis Assemblage-Zone, and Olenoides and Burlingia in that zone and the Oryctocephalus indicus Zone as well. This combination of taxa enables a precise stratigraphic correlation into the Siberia, Greenland, and Laurentia (Geyer and Peel, 2011; Sundberg et al., 2016). In addition, based on the important trilobite taxa Acadoparadoxides, Eccaparadoxides and Micmacca, the base of the Wuliuan Stage can be correlated across the Mediterranean region (e.g., Morocco, Turkey and Spain) and also to Siberia and Australia (Liñán et al., 2004, 2008; Gozalo et al., 2007, 2011a, b; Geyer, 2016) although direct correlation of Mediterranean successions to other continents is difficult (Álvaro et al., 2003, 2013; Gozolo et al., 2007; Sundberg et al., 2010, 2016; Geyer and Peel, 2011; Zhao et al., 2012a). However, with the aid of Siberian taxa, the base of the Wuliuan Stage can be correlated, more or less confidently, with that of the Mediterranean region.

\section{Stratotype Section and Point}

The stratotype Wuliu-Zengjiayan section consists mainly of the Kaili Formation that rests conformably on the Tsinghsutung Formation and is overlain conformably by the Jia- 
lao Formation (Figs. 4(a), 5, 7, 9). Both the Tsinghsutung and Jialao formations are of dolomite facies.

The Kaili Formation in the Wuliu-Zengjiayan section is a mostly monofacial succession of silty mudstone, mudstone, calcareous mudstone and shale with subordinate gray limestone-marlstone in the basal part and limestone in the uppermost parts of the formation (Zhao et al., 2001a, b; Gaines et al., 2011). Soft-sediment deformation, truncation surfaces, and slide surfaces are rare in the section and absent near the GSSP, suggesting deposition on a gentle slope. The interval of the FAD of $O$. indicus is inferred to be a maximum flooding stage of the major eustatic transgression (Zhu et al., 1999; Gaines et al., 2011; Fig. 7).

The Kaili Formation embraces three trilobite zones, including two polymerid zones and one agnostoid zone (Zhao et al., 2012a, c, 2015, 2017; Fig. 5), in ascending order: the Bathynotus kueichouensis-Ovatoryctocra sinensis Assemblage-Zone (4.0-52.8 $\mathrm{m}$ above the base of the Kaili Formation), the Oryctcocephalus indicus Zone (52.8-143.78 $\mathrm{m}$ above the base of the Kaili Formation), and the Peronopsis taijiangensis Zone (143.78-214.2 $\mathrm{m}$ above the base of the Kaili Formation). As mentioned above, the trilobite zonal succession of the Kaili Formation in the Wuliu-Zengjiayan section reveals a complete, tectonically undisturbed, marine succession.

Oryctocephalus indicus makes its first appearance at $52.8 \mathrm{~m}$ above the base of the Kaili Formation (Fig. 6(a)), a level defining the base of the Miaolingian Series and Wuliuan Stage (Zhao et al., 2001a, b, 2006, 2007, 2008, 2012a, 2014; Sundberg et al., 2010, 2011). This point in the Wuliu-Zengjiayan section demonstrates a major change in faunal assemblages with the extinction of redlichiids and Bathynotus and the appearance of several new ptychoparid taxa, although some oryctocephalid taxa exhibit ranges that cross this horizon (Fig. 5). Current stratigraphic resolution suggests that the FAD of $O$. indicus in

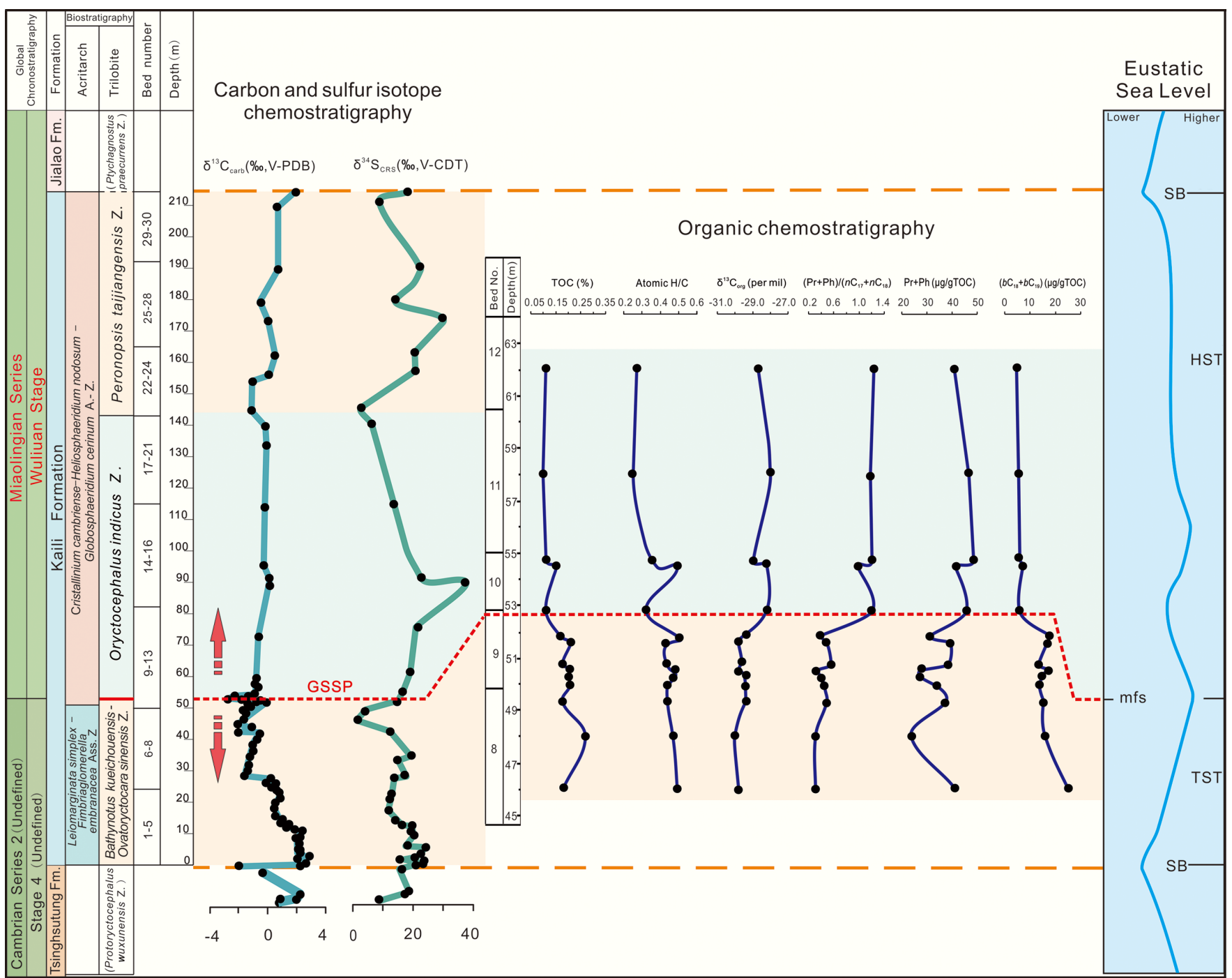

Figure 7. Summary of primary and secondary stratigraphic indicators for the base of the Miaolingian Series and Wuliuan Stage of the Cambrian System. Major stratigraphic tools used to constrain the GSSP of the series and stage are trilobite biostratigraphy (Zhao et al., 2007, 2012, 2015), acritarch biostratigraphy (Yin et al., 2010), carbon and sulfur isotope chemostratigraphy (Guo et al., 2010a, b, 2014), organic chemostratigraphy (Wang et al., 2014) and sequence stratigraphy (Gains et al., 2011). Abbreviations: TOC = total organic carbon content in rocks; atomic $\mathrm{H} / \mathrm{C}=$ atomic hydrogen/carbon ratio; $d^{13} C_{\text {org }}$ data were measured on kerogen samples; $P r=p r i s t a n e ; ~ P h=p h y t a n e ; ~ n C_{17}$, $=n o r m a l$ $C_{17} ; n C_{18}=$ normal $C_{18} ; b_{18}$ and $b C_{19}=C_{18}$ and $C_{19}$ midchain monomethyl branched alkanes, respectively, based on m/z 126+140+154+168+ 196+210+224 mass chromatograms; $m f s=$ maximum flooding surface; $S B=$ sequence boundary; HST = Highstand Systems Tract; TST = Transgressive Systems Tract. 
the major Cambrian realms is equivalent in age. In the Wuliu-Zengjiayan section, $O$. indicus ranges across a $90.98 \mathrm{~m}$ interval, which is well fossiliferous, especially in its lower portion. The high-resolution data on distributions of trilobite taxa through the stratigraphic interval containing the GSSP in the Wuliu-Zengjiayan section are summarized in Fig. 5. In addition to $O$. indicus, a number of other guide fossils, which have utility for correlation on either an intercontinental or an interregional scale, help to constrain the position of the boundary. The major faunal changes below and above the FAD of $O$. indicus provide excellent data for global correlation of the boundary interval of the Wuliuan Stage. Among the key trilobite levels in the boundary interval, the LADs of Ovatoryctocara sinensis ( $48.8 \mathrm{~m}$ above the base of the Kaili Formation, Figs. 5, 6(f)) and Bathynotus kueichouensis (48.8 $\mathrm{m}$ above the base of the Kaili Formation, Figs. 5, 6(g-h)) can serve as second- ary biostratigraphic correlation tools for identifying, with more or less precision, the base of the Miaolingian Series and the Wuliuan Stage (Zhao et al., 2001a, b, 2007, 2012c, 2014; Geyer, 2005; Fletcher, 2007; Peng et al., 2009; Sundberg et al., 2011).

The Wuliu-Zengjiayan section bears exceptionally preserved Burgess-type biota, termed the Kaili Biota. The biota occurs slightly above the FAD of Oryctocephalus indicus, containing representatives of at least 11 phyla that include algae, sponges, chancelloriids, cnidarians, "worms", lobopodia, medusiform fossils, brachiopods, molluscs, arthropods, echinoderms and various problematic fossils, of which some of the taxa are non-biomineralizing (Zhao et al., 2005, 2011; Fig. 8). This important biota can serve to constrain the position of the base of the Miaolingian Series and Wuliuan Stage at least in South China.

Besides trilobites and the exceptionally preserved taxa of the Kaili
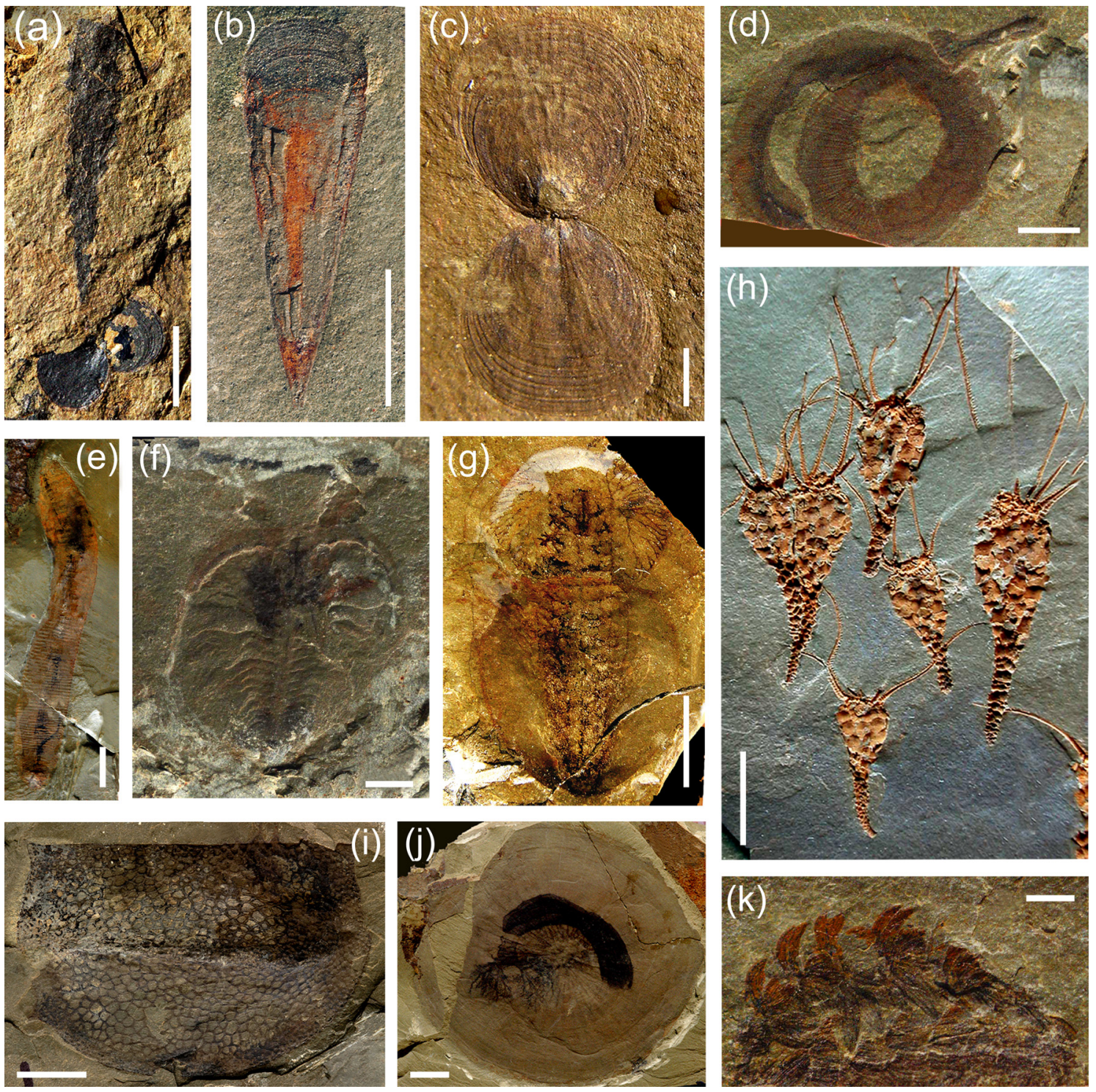

Figure 8. Some metazoan taxa from the exceptionally preserved Kaili Biota in Balang Area, Jianhe, Guizhou. (a) Angulosuspongia sinensis Yang, Babcock et Peng, 2017 attached to Glyptacrothele bohemica, GTBM-9-2-1971; (b) Haplophrentis cf. H. carinatus Matthew, 1899, GTBM-9-3162; (c) Acrothele sp., GTBM-9-5365; (d) Palaeoscolecid, gen. et sp. indet., GTBM-9-1b; (e) Ottoia guizhouensis Yang, Zhao et Zhang, 2016, GTBM-9-4166; (f) Marrella sp., ventral view, GTBM-9-5-1075; (g) Naraoia cf. N. compacta Walcott, 1912, showing thin vessels in cephalic area, GTBM-9-3-5098; (h) Sinoeocrinus lui Zhao, Huang et Gong, 1994, GTB-9-5-3495; (i) Tuzoia bispinosa Yuan et Zhao, 1999, GM 9-5-1248; (j) Pararotadiscus guizhouensis Zhao and Zhu, 1994, GTBJ-13-3-220; (k) Wiwaxia taijiangensis Zhao, Qian et Li., 1994, with articulated specimen, GTBM-9-5-8888a. Scale bars equal $5 \mathrm{~mm}$ for (a), (b), (e), (g), (i); $10 \mathrm{~mm}$ for (h), (j) and 2 mm for others. 


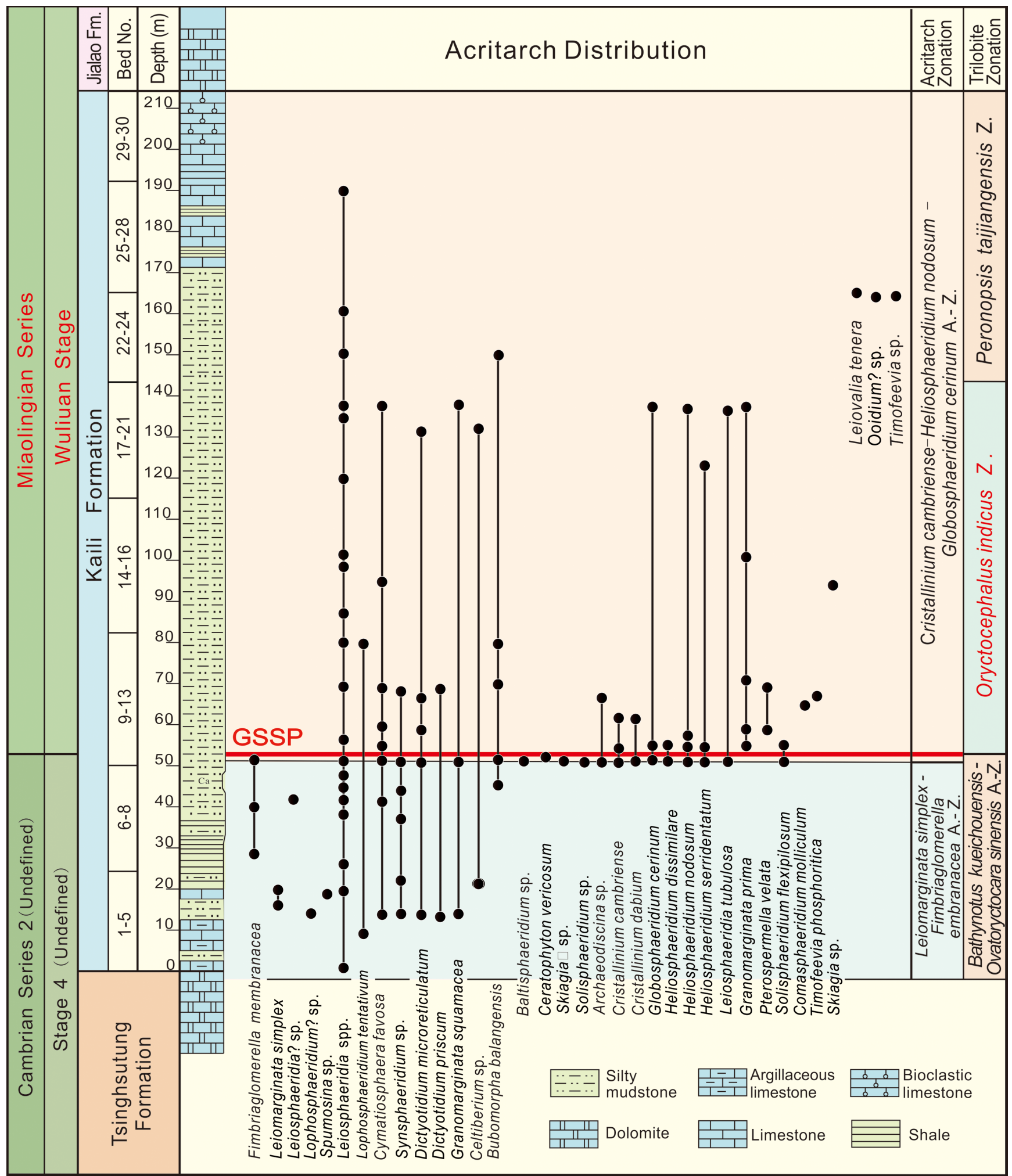

Figure 9. Observed stratigraphic distribution of acritarchs in the Kaili Formation of the Wuliu-Zengjiayan GSSP section (modified from Yin et al., 2010).

Biota, the acritarch assemblage from the Wuliu-Zengjiayan section shows a prominent change close to the FAD of Oryctocephalus indicus (Yin and Yang, 1999; Yang and Yin, 2001; Yin et al., 2009, 2010; Figs. 9, 10). The Leiomarginata simplex-Fimbriaglomerella membranacea assemblage (0-52 $\mathrm{m}$ above the base of the Kaili Formation) below the datum is clearly replaced by the Cristallinium cambrienseHeliosphaeridium nodosum-Globosphaeridium cerinum assemblage (52-140 $\mathrm{m}$ above the base of the Kaili Formation). This turnover in microfossil assemblages closely corresponds with the major change in trilobite assemblages (Yin and Yang, 1999; Yin et al., 2009). This 
result has been confirmed by detailed, bed-by-bed sampling for palynomorphs across a $4 \mathrm{~m}$ interval bearing the FAD of $O$. indicus $(50.8-$ $54.8 \mathrm{~m}$ in Wuliu quarry, Fig. 4(b), (d)) (see Yin et al., 2010). Thus, the acritarch assemblages also help to constrain the base of the Miaolingian Series and Wuliuan Stage, and provide another fossil tool for correlating the boundary interval of South China to those of Baltica and Gondwana, in which the acritarch biostratigraphy has been reported in details (Volkova, 1990; Moczydłowska, 1998, 1999; Palacios, 2015; Moczydłowska and Yin, 2012).

\section{Regional and Global Correlation}

The FAD of Oryctocephalus indicus in the stratotype Wuliu-Zengjiayan section is one of the most easily recognizable horizons in the Cambrian (see Geyer and Shergold, 2000; Fig. 2). In South China, it is used for defining the base of the regional Wulingian Series and Taijiangian Stage (Peng et al., 2000; Peng and Babcock, 2001). Possible suitability of the FAD of this species for marking a global stage and series boundary has been summarized principally by Shergold and Geyer (2003), and Peng et al. (2004a, b, 2006). Key correlation tools are biostratigraphic ranges of polymerid trilobites, agnostoid trilobites, acritarchs; carbon isotopic ratios; sulfur isotopic ratios; and organic chemostratigraphy; and sequence stratigraphy.

\section{Polymerid Trilobite Biostratigraphy}

Two polymerid biozones are recognized in the lower-middle part of the Wuliu-Zengjiayan section (Zhao et al., 2001a, b, 2012a, c, 2015, 2017; Yuan et al., 2002), the lower Bathynotus kueichouensis-Ovatoryctocara sinensis Assemblage-Zone and the overlying Oryctocephalus indicus Zone (the lowermost zone of the Wuliuan Stage) with their boundary defined by the FAD of $O$. indicus (Figs. 4(a), 5). These two zones have been recognized in a number of sections of the Kaili Formation in eastern Guizhou, for example, the Miaobanpo (Zhao et al., 2001a, b, 2005, 2011), the Jianshan (Zhao et al., 2008), the Fujiachong (Zhao et al., 2012a), the Sanwan (Zhao et al., 2012b) and the Pingzhai (Yuan et al., 2002; Zhao et al., 2012a) sections. The level coinciding with FAD of $O$. indicus may correlate to the base of the Tianpeng Formation of platform facies in Mengzi County of Yunnan Province, South China (Zhao et al., 2014), the base of Amecephalus arrojosensis Zone of Emigrant Formation in Great Basin, USA, and occurs in the Parahio Formation, Spiti area, Indian Himalaya (see Singh et al., 2016; Hughes et al., 2018), and the corresponding level in northwestern Korea (Saito, 1934).

Although most of the polymerid trilobites from the biozones are endemic, a few of them provide, more or less, correlation tools of regional or intercontinental scale and allow tielines to be established into some other Cambrian faunal realms. Particularly useful guide fossils are the pandemic forms such as Oryctocephalus indicus, Ovatoryctocara, Oryctocephalops, Oryctocephalites, and Burlingia (Reed, 1910; Saito, 1934; Lermontova, 1940; Shergold, 1969; Lu et al., 1974; Zhang et al., 1980; Whittington, 1994; Jell and Hughes, 1997; Sundberg and McCollum, 1997, 2003; Yuan et al., 1997, 2002; Zhao et al., 2001a, b, 2006, 2012b, 2014; Sundberg et al., 2011, 2016; Geyer and Peel, 2011; Yuan and Esteve, 2015; Hughes, 2016; Singh et al., 2016; Esteve et al.,
2017), the nektobenthic forms such as Redlichia and Bathynotus (Kobayashi, 1935; Lu, 1950; Lu and Chien, 1964; Öpik, 1970; Zhang et al., 1980; Whittington, 1988; Guo et al., 1999; Shergold and Whittington, 2000; Yuan et al., 2002; Kruse et al., 2004; Peng et al., 2009, 2014; Webster, 2009; Goryaeva et al., 2012; Hughes, 2016; Laurie, 2016), and the benthic trilobite Olenoides that has an intercontinental distribution (Yuan et al., 1997, 2002; Wang et al., 2016).

\section{Agnostoid Trilobite Biostratigraphy}

A single agnostoid biozone, the Peronopsis taijiangensis Zone, is recognized in the upper part of the Wuliu-Zengjiayan section (Yao et al., 2009), replacing the previous Oryctocephalus orientalis Zone of Yuan et al. (2002). It lies immediately above the Oryctocephalus indicus Zone (Fig. 5), and in eastern Guizhou and western Hunan it is overlain by the agnostoid Ptychagnostus gibbus Zone of the Huaqiao Formation (Peng, 2009, 2018). The Peronopsis taijiangensis Zone is correlatable with the Ptychagnotus praecurrens Zone of Laurentia, where the agnostoid Ptychagnotus praecurrens Zone, together with the overlying Ptychagnotus gibbus Zone, correlates with the upper half of the polymerid Oryctocephalus Zone (Robison and Babcock, 2011; Babcock et al., 2017). Ptychagnotus praecurrens is a widespread agnostoid trilobite, known from Sweden (Westergård, 1946; Weidner and Ebbestad, 2014; Ahlberg et al., 2019), England (Rushton, 1966), Russia (Siberia) (Egorova et al., 1976; Naimark, 2008; Shabanov et al.,2008), Australia (Laurie, 2004; Kruse et al., 2009), the USA (Utah and Nevada) (Robison, 1982; McCollum and Sundberg, 2007, Sundberg, 2011), and probably from Kazakhstan (Ergaliev and Ergaliev, 2008).

Although Ptychagnotus praecurrens has not been recorded in South China (likely due to facies restriction), strata corresponding to the $P$. praecurrens Zone are apparently present, i.e. the Aoxi Formation in northwestern Hunan, which is composed of grey to light grey, thin- to thick-bedded dolomites but straigraphically is overlain by the P. gibbus-bearing Huaqiao Formation (Peng and Robison, 2000). In the Wuliu-Zengjiayan section, the eodiscid trilobite Pagetia significans makes its first appearance slightly below the FAD of $O$. indicus (Sundberg et al., 2016; Fig. 5). Pagetia significans has been recorded from the Miaolingian strata of Australia (Jell, 1975), North Korea (Kobayashi, 1944), and Indian Himalaya (Jell and Hughes, 1997; Singh et al., 2016).

\section{Acritarch Biostratigraphy}

As phytoplanktic microfossils, Cambrian acritarchs are of significance to assist in delineating faunal zones, for indicating changes in the depositional environment, and even defining geological or biological events.

The taxonomic change in organic-walled microfossils (acritarchs) in the Wuliu-Zengjiayan section has been intensively studied (Yin et al., 2010). As discussed above, two acritarch assemblages, the Leiomarginata simplex-Fimbriaglomerella membranacea assemblage and the Cristallinium cambriense-Heliosphaeridium nodosum-Globosphaeridium cerinum assemblage are recognized below and above the GSSP respectively (Fig. 9). These acritarch assemblage zones are based on continuous sampling of the whole section, and more intensive sampling across a $4 \mathrm{~m}$ interval (50.8-54.8 $\mathrm{m}$ above the base of the Kaili Formation). Many acanthomorphic acritarch forms, such as Helios- 


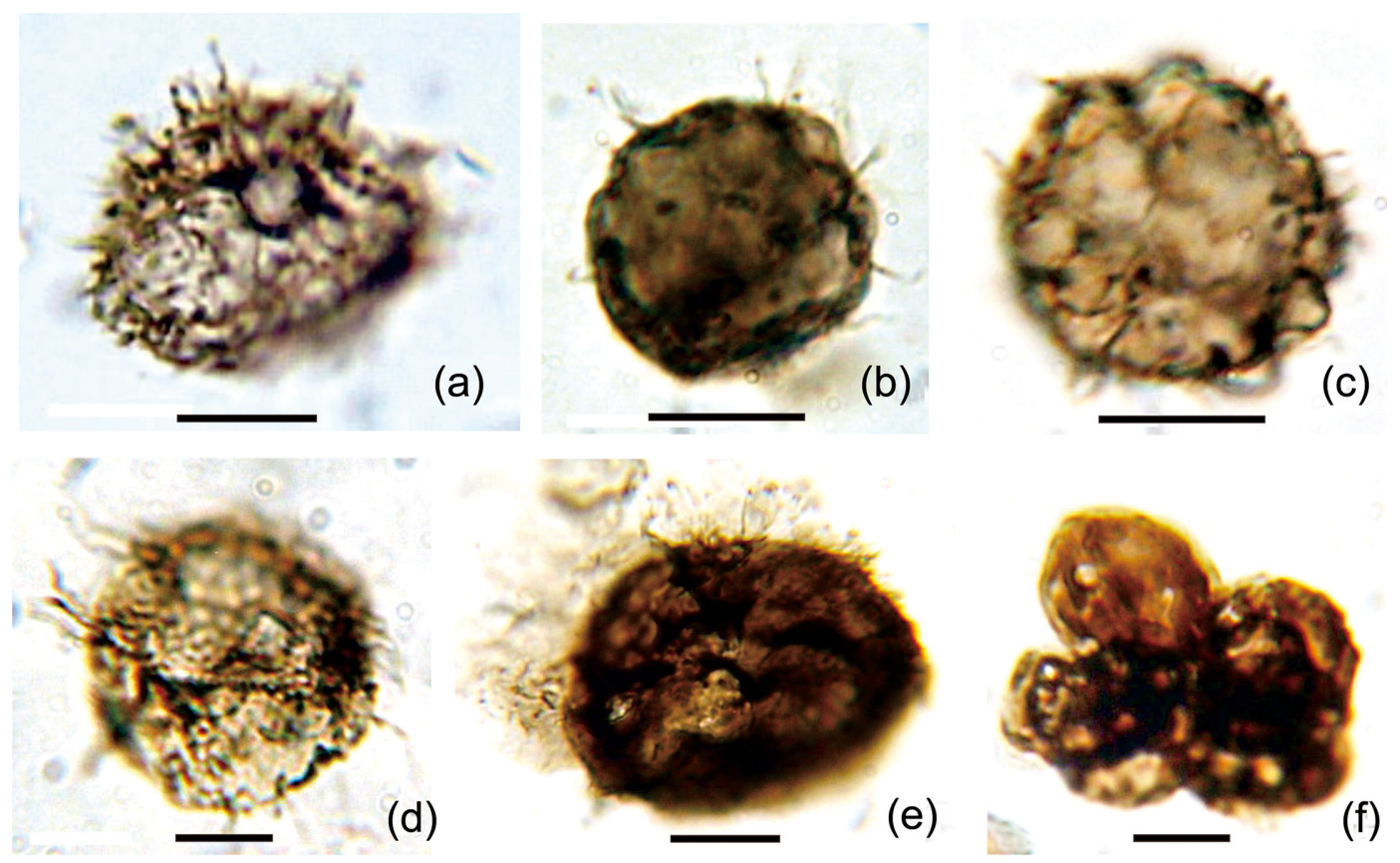

Figure 10. Acritarchs from the Kaili Formation of the Wuliu-Zengjiayan section. Sample numbers are prefixed with either FZX or K. (a) Heliosphaeridium nodosum Moczydtowska, 1998, FZX25; (b), (c) Globosphaeridium cerinum (Volkova) comb. Moczydtowska, 1991, FZX25b, FZX24c; (d) Solisphaeridium flexipilosum (Slavicova) comb. Moczydlowska, 1998, FZX26; (e) Comasphaeridium molliculum Moczydlowska and Vidal, 1988, K69; (f) Synsphaeridium sp., K51. All scale bars equal $10 \mu m$.

phaeridium dissimilare, H. nodosum, H. serridentatum, Globosphaeridium cerinum, and Solisphaeridium flexipilosum (Fig. 10), exhibit a first appearance at 52.3-52.7 $\mathrm{m}$ above the base of the Kaili Formation), which is slightly below the GSSP for the base of Miaolingian Series and Wuliuan Stage.

Heliosphaeridium nodosum, H. dissimilare, H. serridentatum, Globosphaeridium cerinum, Solisphaeridium frixipilosum also mark the base of the traditional middle Cambrian in Baltica, and Gondwana (Volkova, 1990; Moczydłowska,1998, 1999; Moczydłowska and Yin, 2012; Palacios, 2015). On the basis of the present record and existing data, it is noted that many species referred to Heliosphaeridium range from the provisional Cambrian Series 2 through the Miaolingian Series are even restricted to the Miaolingian Series. Therefore, certain species of Heliosphaeeridium, such as $H$. dissimilare and H. serridentatum, appear to characterize the Miaolingian Series.

More recently, acritarch assemblages and cryptospore-like microfossils have been obtained from stratigraphic successions spanning the Oryctocephalus indicus Zone in the Parahio Valley (Spiti), Indian Himalaya, and the Log Cabin Mine section, eastern Nevada, USA (Yin et al., 2013), showing the obvious change in acritarch taxonomy near the FAD of Oryctocephalus indicus. Such a change is significant and indicates an important geobiological event (Yin et al., 2016).

\section{Carbon Isotope Chemostratigraphy}

The carbon isotopic composition of carbonate rocks varies between -2.7 and $+3.1 \%$ in the Wuliu-Zengjiayan section (Yang et al., 2003; Guo et al., 2005, 2010a, b). There is a stepwise decline from the base of the Kaili Formation towards the GSSP level, which is marked by peak negative values. Subsequently, there is a long relative stable interval with average seawater values between 0 and 1 , and then the formation top (last sample) has a minor positive excursion. The base of the Oryctocephalus indicus Zone is marked by a distinctive peak of a rather long negative $\delta^{13} \mathrm{C}_{\text {carb }}$ excursion with minimum values of $-2.7 \%$ o (Fig. 7). Thus, a distinct negative excursion in the carbon isotopic composition occurs from the Bathynotus kueichouensis-Ovatoryctocara sinensis Assemblage-Zone through the $O$. indicus Zone. This excursion, near the conterminous base of the Miaolingian Series and Wuliuan Stage, can also be recognized at the Jianshan section nearby (Guo et al., 2010a, b), at other localities on the Yangtze Platform, South China (Zhu et al., 2004), in Siberia (Shabanov et al., 2008), and North America (Montañez et al., 2000; Dilliard et al., 2007).

\section{Sulfur Isotope Chemostratigraphy}

The sulfur isotopic composition of sedimentary pyrite displays a similar variation across the provisional Cambrian Series 2 through the Miaolingian Series in the Wuliu-Zengjiayan section (Guo et al., 2014). A shift from $\delta^{34} \mathrm{~S}_{\mathrm{CRS}}$ values around $1.3 \%$ to more positive values of $19.8 \%$ through the lower part of Kaili Formation. An excursion towards less ${ }^{34} \mathrm{~S}$ enriched values is located slightly below the level of the Cambrian Series 2 to Cambrian Series 3 transition. There are two separate positive excursions in the middle and upper Kaili Formation, and an additional third one occurs at the formation top. The evolution towards more positive $\delta^{34} \mathrm{~S}$ values could reflect the development of closed system conditions in the early burial environment with respect to sulfate availability in the pore water realm. Comparably ${ }^{34} \mathrm{~S}$ enriched pyrite sulfur isotope values and a somewhat similar variation across this stratigraphic transition have been observed in other sections of northwest Spain (Wotte et al., 2012), southern France (Wotte et al., 2012), the 
Siberian Platform (Wotte et al., 2011), the USA (Wotte et al., 2011), and Mexico (Loyd et al., 2012).

\section{Organic Chemostratigraphy}

Organic geochemical investigations for the boundary interval of the Wuliu-Zengjiayan GSSP section (Bed 8-12) shows that all the geochemical proxies, such as TOC content, $\delta^{13} \mathrm{C}_{\text {org }}$, atomic $\mathrm{H} / \mathrm{C}$ value of kerogen, as well as biomarker parameters, co-vary across the section and change rather sharply across the boundary between the provisional Cambrian Series 2 and the Miaolingian Series at the top of Bed 9 (Wang et al., 2014; Fig. 7). For example, the relative abundance of isoprenoid hydrocarbons to $n$-alkanes (or the absolute concentration to TOC) shows an upward increase across the boundary with the $(\mathrm{Pr}+\mathrm{Ph}) /\left(n \mathrm{C}_{17}+n \mathrm{C}_{18}\right)$ values ranging in $0.31-0.56$ in the provisional Stage 4 sediments, as compared to $0.98-1.24$ in the Wuliuan Stage. The $\delta^{13} \mathrm{C}_{\text {org }}$ trend is also in accord with the abrupt change in $\delta^{13} \mathrm{C}_{\text {carb }}$ across the boundary (Guo et al., 2010a, b; Fig. 7).

In general, changes observed are interpreted to reflect primary depositional values, notably variations in the composition of primary productivity and the marine redox condition (Wang et al., 2014). These, in turn, are linked to biological changes (i.e. trilobites and acritarchs respectively; Figs. 5, 6, 9, 10) and a possible regional and global anoxiaextinction event across the transition from the Series 2 to the Miaolingian Series. The extinction of multiple trilobite species at the end of Series 2 is probably related to global anoxia as evidenced by carbon and sulfur isotopes (Guo et al., 2010a, b, 2014; Fig. 7) and organic geochemical result (Wang et al., 2014). Evidently, the organic chemostratigraphic evidences also strongly support to place the base of the Miaolingian Series and Wuliuan Stage at this level.

\section{Sequence Stratigraphy}

Sea level changes corresponding to 3rd and 4th order depositional cycles (Fig. 7) caused migration of the adjacent Yangtze carbonate platform, the proximity of which controlled the amount of carbonate sediment delivered to the open-shelf to slope settings upon which the Kaili Formation was deposited. Initial Kaili deposition represents the onset of flooding on the slope. The lower portion of the Kaili Formation has been interpreted to represent a transgressive interval, with maximum flooding in the interval surrounding the GSSP at $52.8 \mathrm{~m}$ above the base of the formation (Gaines et al., 2011). The remaining thickness of the middle and upper Kaili Formation is interpreted as a highstand system tract with gradual shallowing and accompanying seaward progradation of the Yangtze carbonate platform, manifested an overall increase in the presence of thin, interbedded carbonates upsection toward the contact with the overlying mixed-siliciclastic carbonate Jialao Formation. The Kaili-Jialao succession has been interpreted to be a complete $3 \mathrm{rd}$ order depositional cycle, representing transgression, maximum flooding, and a protracted period of regression accompanied by basin filling (Wang et al., 2006).

\section{Other Regional Reference Sections}

For comparative purposes, the Jianshan and Sanwan sections in eastern Guizhou have been studied in detail (Zhao et al., 2008, 2012b). Both sections bear the FAD of Oryctocephalus indicus and also fulfill, more or less, the biostratigraphic requirements for a GSSP. Both sections are available with unrestricted access for research purposes. The Sanwan section appears to be a good auxiliary to the Wuliu-Zengjiayan GSSP section if it could receive intensive study in future. The Jianshan section is similar to the Wuliu-Zengjiayan section in lithoand bio-stratigraphic features, but it bears a small tectonic fold within the $O$. indicus Zone (at $c a .78 .5 \mathrm{~m}$ above the base of the Kaili Formation) (Zhao et al., 2008).

\section{Best Estimate of Age for the Base of the Proposed Miaolingian Series and Wuliuan Stage}

The age for the base of Miaolingian Series and Wuliuan Stage is estimated at $509.1 \pm 0.22 \mathrm{Ma}$. This age is based on an ash bed in the Upper Comley Sandstone of Shropshire, United Kingdom, which has given a weighted mean ${ }^{206} \mathrm{~Pb} /{ }^{238} \mathrm{U}$ age of $509.02 \pm 0.79 \mathrm{Ma}$ on four (of six) single grain fractions (Harvey et al., 2011). This age was newly recalibrated to $509.1 \pm 0.62$ (with $\lambda$ errors) by the Isotope Geology Laboratory of Boise State University, USA, as one of the high-resolution radiometric ages of zircon crystals determined by TIMS for the International Commission on Stratigraphy (Peng et al., 2012b; Schmitz, 2012). From immediately overlying beds, trilobites including Paradoxides harlani indicate the P. harlani Zone of Newfoundland, which is correlatable with the Oryctocephalus indicus Zone of South China and Laurentia (Geyer, 2005; Fletcher, 2007), and the base of the traditional 'Middle Cambrian' (St. David's Series) in Shropshire. The base of the traditional Middle Cambrian is estimated to be $510.0 \pm 1.0 \mathrm{Ma}$, an age that is constrained by U-Pb zircon ages from an ash bed in the Hanford Brook Formation, southern New Brunswick (Bowring and Erwin, 1998; Landing et al., 1998). This age was recalibrated as $508.05 \pm$ 2.5 Ma (Peng et al., 2012b; Schmitz, 2012). Although the age of the stratigraphically older New Brunswick ash bed conflicts with the above estimated age for the base of Wuliuan Stage (509.1 $\pm 0.62 \mathrm{Ma})$, the conflict is easily accommodated within the error ranges for the two dates. Taken together, the two dates give a well-corroborated age for the base of the Miaolingian Series and Wuliuan Stage close to $509 \mathrm{Ma}$. Montañez et al. (2000) estimated an age of $\sim 509$ Ma for the base of the traditional Middle Cambrian of Laurentia, and this estimate is close to the age provided by ICS.

\section{Acknowledgements}

We thank the members of the Working Group on Cambrian Stage 5, International Subcommission on Cambrian Stratigraphy (ISCS), and the voting members of ISCS for providing constructive comments and suggestions that improved the original proposal largely. This work was supported in part by grants from the National Natural Science Foundation of China (49060010, 40372023, 41330101), the Ministry of Science and Technology of China (2006CB806401, 2013CB835002, 2015FY310100, 12002CC2600), the National Commission on Stratigraphy of China (95-Special Project-01-1-6, DD20160120-04), the State Key Laboratory on Palaeobiology and Stratigraphy (20191101), 
and the Guizhou Bureau of Science and Technology (CGSCFG-20107001; Gui. Sci. Tal. [2017] 5788). Zhu Lijun and Yu Meiyi from the Guizhou University and Zhang Zhenghua from the Guizhou Command of Southwest Petroleum are thanked for taking part in earlier studies of the GSSP. We are grateful to Nigel C. Hughes (Riverside) and an anonymous reviewer for their constructive reviews. Special thanks are due to all master students from the College of Resource and Environment Engineering, Guizhou University, and to the local Balang villager Feng Liu and Zhefu Liu for their assistance with the field work. This is a contribution to the IGCP 668 project 'The stratigraphic and magmatic history of Early Paleozoic equatorial Gondwana and its associated evolutionary Dynamics.'

\section{References}

Ahlberg, P., Lundberg, F., Erlström, M., Calner, M., Lingskog, A., Dahlqvist, P., and Joachimski, M.M., 2019. Integrated Cambrian biostratigraphy and carbon isotope chemostratigraphy of the Grönhögen2015 drill core, land, Sweden. Geological Magazine, v. 156(6): pp. 935-949.

Álvaro, J.J., Ahlberg, P., Babcock, L.E., Bordonaro, O.L., Choi, D.K., Cooper, R.A., Ergaliev, G.K., Gapp, I.W., Ghobadi Pour, M., Hughes, N.C., Jago, J.B., Korovnikov, I.V., Laurie, J.R., Lieberman, B.S., Paterson, J.R., Pegel, T.V., Popov, L.E., Rushton, A.W.A., Sukhov, S.S., Tortello, M.F., Zhou, Z.Y., and Żylińska, A., 2013. Global Cambrian trilobite palaeobiogeography assessed using parsimony analysis of endemicity. In: Harper, D.A.T., Servais, T. (Eds.), Early Palaeozoic biogeography and palaeogeography. Geological Society of London Memoirs, v. 38, pp. 273-296.

Álvaro, J.J., Elick, O., Geyer, G., Rushton, A.W.A., and Shergold, J.H., 2003. Palaeogeographical controls on the Cambrian trilobite immigration and evolutionary patterns reported in the western Gondwana margin. Palaeogeography, Palaeoclimatology, Palaeoecology, v. 195(1-2), pp. 5-35.

Astashkin, V.A., Pegel, T.V., Shabanov, Y.Y., Sukhov, S.S., Sundukov, V.M., Repina, L.N., Rozanov, A.Y., and Zhuravlev, A.Y., 1991. The Cambrian System on the Siberian Platform correlation chart and explanatory notes. International Union of Geological Science, Publication, v. 27, pp. 1-133.

Babcock, L.E., and Peng, S.C., 2007. Cambrian chronostratigraphy: current state and future plans. Palaeogeography, Palaeoclimatology, Palaeoecology, v. 254, pp. 62-66.

Babcock, L.E., Rees, M.N., Robison, R.A., Langenburg, E.S., and Peng, S.C., 2004. Potential Global Stratotype Section and Point (GSSP) for a Cambrian stage boundary defined by the first appearance of the trilobite Ptychagnostus atavus, Drum Mountains, Utah, USA. Geobios, v. 37(2), pp. 149-158.

Babcock, L. E., Peng, S. C., Geyer, G., and Shergold, J. H., 2005. Changing perspectives on Cambrian chronostratigraphy and progress toward subdivision of the Cambrian System. Geoscience Journal, v. 9, pp. 101-106.

Babcock, L.E., Robison, R.A., Rees, M.N., Peng, S.C., and Saltzman, M.R., 2007. The Global boundary Stratotype Section and Point (GSSP) of the Drumian Stage (Cambrian) in the Drum Mountains, Utah, USA. Episodes, v. 30 (2), pp. 85-95.

Babcock, L.E., Peng, S.C., Brett, C. E., Zhu, M.Y., Ahlberg, P., and Bevis, M., 2014. Evidence of global climatic and sea level cycles in the Cambrian, p. 9-11. In: Zhang, R.B. Huang B., 2014. IGCP Project 591 Field Workshop 2014, Extended Summery. Nanjing: Nanjing University Press, Nanjing, pp. 9-11.

Babcock, L.E., Peng, S.C., and Ahlberg, P. 2017: Cambrian trilobite bio- stratigraphy and its role in developing an integrated history of the Earth system. Lethaia, v. 50, pp. 381-399.

Bowring, S.A., and Erwin, D.H., 1998. A new look at evolutionary rates in deep time: uniting Paleontology and high-precision geochronology. GSA Today, v. 8, pp. 1-8.

Brasier, M.D., Cowie, J., Taylor, M., 1994. Decision on the PrecambrianCambrian boundary stratotype. Episodes, v. 17(1), pp. 3-8.

Dilliard, K.A., Pope, M.C., Coniglio, M., Hasiotis, S.T., and Lieberman, B.S., 2007. Stable isotope geochemistry of the lower Cambrian Sekwi Formation, Northwest Territories, Canada: implications for ocean chemistry and secular curve generation. Palaeogeography Palaeoclimatology Palaeoecology, v. 256, pp. 174-194.

Egorova, L.I., Shabanov, Y.Y., Rozanov, A.Y., Savitzky, V.E., Tchernysheva, N.E., and Shishskin, B.B., 1976. Elanska and Kuonamka facies stratotypes of the lower boundary of the Middle Cambrian in Siberia. Trudy Sibirskiy Nauchno-issledovat'skiy Institut Geologiy, Geofiziki i Mineral'nogo Syr'ya (SNIIGGIMS), v. 211, pp. 1-168.

Ergaliev, G.Kh., and Ergaliev, F.G., 2008. Middle and Upper Cambrian Agnostida of the Aksai National Geological Reserve, South Kazakhstan (Kyrshabatky River, Malyi Karatau Range). Palaeontological Institute Almaty, Gylym, 359 p.

Esteve, J., Zhao, Y.L., and Peng, J., 2017. Morphological assessment of the Cambrian trilobites Oryctocephalus indicus (Reed 1910) from China and Oryctocephalus 'reticulatus' (Lermontova 1940) from Siberia. Lethaia, v. 50, pp. 175-193.

Fletcher, T.P., 2007. The base of Cambrian Series 3: the global significance of key oryctocephalid trilobite ranges in the Kaili Formation of South China. Memoir of Association of Australasian Palaeontologists, v. 33, pp. 29-33.

Gaines, R.R., Mering, J.A. Zhao, Y.L., and Peng, J., 2011. Stratigraphic and microfacies analysis of the Kaili Formation, a candidate GSSP for the Cambrian Series 2-Series 3 boundary. Palaeogeography, Palaeoclimatology, Palaeoecology, v. 311(3-4), pp. 171-183.

Gehling, J.G., Jensen, S., Droser, M.L., Myrow, P.M., and Narbonne, G.M., 2001. Burrowing below the basal Cambrian GSSP, Fortune Head, Newfoundland. Geological Magazine, v, 138(2), pp. 213-218.

Geological Survey of Guizhou Province, 1966. Geological Map of Zhenyuan Sheet, 1:200,000. Guizhou Bureau of Geology, Guiyan.

Geyer, G., 2005. The base of a revised Middle Cambrian: are suitable concepts for a series boundary in reach? Geosciences Journal, v. 9, pp. 81-99.

Geyer, G., 2015. Exotic trilobites from the Lower-Middle Cambrian boundary interval in Morocco and their bearing on the Cambrian Series 3 lower boundary. Paläontologische Zeitschrift, v. 89(4), pp. 749-781.

Geyer, G., 2016. Taxonomy of the 'Micmacca' group, new Cambrian Chengkouiidae (Trilobita) from Morocco, and their bearing on international correlation. In: Laurie, J.R., Percival, I.G., Jago,J.B., Paterson, J.R., and Brock, G.A. (Eds.), Cambro-Ordovician Studies VI. Australasian Palaeontological Memoir, v. 49, pp. 329-393.

Geyer, G., and Peel, S.J., 2011. The Henson Gletscher Formation of North Greenland and its bearing on the global Cambrian Series 2-Series 3 boundary. Bulletin of Geosciences, v. 86(3), pp. 465-534.

Geyer, G., and Shergold, J., 2000. The quest for internationally recognized divisions of Cambrian time. Episodes, v. 23, pp. 188-195.

Goryaeva, I.E., Pegel, T.V., Shabanov, Y.Y., and Bushuev, E.V., 2012. New data on stratigraphic range of trilobite Bathynotus genus in the Cambrian of the Siberian Platform. In: Zhao, Y.L., Zhu, M.Y., Peng, J., Gaines, R.R., and Parsley, R.L. (Eds.), Cryogenian-Ediacaran to Cambrian Stratigraphy and Paleontology of Guizhou, China. Journal of Guizhou University (Natural Science), v. 29 (Supplement 1), p. 64.

Gozalo, R., Liñán, E., Dies Álvarez, M.E., Gámez Vintaned, J.A., and Mayoral, E., 2007. The Lower-Middle Cambrian boundary in the Mediterranean subprovince. In: Linnemann, U., Nance, R.D., Kraft, P., and Zulauf, G. (Eds.), The Evolution of the Rheic Ocean: From Avalonian-Cadomian Active Margin to Alleghenian-Variscan Collision. Geological Society of America Special Paper, v. 423, pp. 359-373. 
Gozalo, R., Bautista, J., Chirivella Martorell, J.B., Esteve, J., and Liñán, E., 2011a. Correlation between the base of Drumian Stage and the base of middle Caesaraugustan Stage in the Iberian Chains (NE Spain). Bulletin of Geosciences, v. 86(3), pp. 545-554.

Gozalo, R., Liñán, E., and Chirivella Martorell, J.B., 2011b. The first record of Dinesus (Trilobita, Dinesidae) in the Cambrian of the Mediterranean region. Alcheringa, v. 35(1), pp. 1-9.

Guizhou Bureau of Geology and Mineral Resources, 1987. Regional Geology of Guizhou Province. People's Republic of China, Ministry of Geology and Mineral Resources, Geological Memoirs, Series 1, Number 7. Geological Publishing House, Beijing, 698 p.

Guo, Q.J. and Zhao, Y.L., 1998. The Discovery and Significance of Redlichia from the Lower part of Lower -middle Cambrian Kaili Formation. Joural of Guizhou University of Technology, v. 27(1), pp. 51-55.

Guo, Q.J., Zhao, Y.L., and Yuan, J.L., 1999. The restudy of Redlichia from the lower part of the Kaili Formation in Kaili area, Guizhou Province. Acta Palaeontologica Sinica, v. 38(Supplement), pp. 157-164.

Guo, Q.J., Strauss, H., Liu, C.Q., Zhao, Y.L., Pi, D.H., Fu, P.Q., Zhu, L.J., and Yang, R.D., 2005. Carbon and oxygen isotopic composition of Lower to Middle Cambrian sediments at Taijiang, Guizhou Province, China. Geological Magazine, v. 142(6), pp. 723-733.

Guo, Q.J., Strauss, H., Liu, C.Q., Zhao, Y.L., Yang, X.L., Peng, J., and Yang, H., 2010a. A negative carbon isotope excursion defines the transition from Cambrian Series 2 to Cambrian Series 3 on the Yangtze Platform, South China. Palaeogeography, Palaeoclimatology, Palaeoecology, v. 285, pp. 143-151.

Guo, Q.J., Strauss, H., Liu, C.Q., Zhao, Y.L., Yang, X.L., Peng, J., and Yang, H., 2010b. Corrigendum to "A negative carbon isotope excursion defines the boundary from Cambrian Series 2 to Cambrian Series 3 on the Yangtze Platform, South China" [Palaeogeography, Palaeoclimatology, Palaeoecology, 285, 143-151]. Palaeogeography, Palaeoclimatology, Palaeoecology, v. 288, p. 118.

Guo, Q.J., Strauss, H., Zhao, Y.L, Yang, X.L., Peng, J., Yang, Y.N., and Deng, Y.N., 2014. Reconstructing marine redox conditions for the transition between Cambrian Series 2 and Cambrian Series 3, Kaili area, Yangtze Platform: Evidence from biogenic sulfur and degree of pyritization. Palaeogeography, Palaeoclimatology, Palaeoecology, v. 398(2), pp. 144-153.

Harvey, T.H.P, Williams, M., Condon, D.J., Wilby, P.R., Siveter, D.J., Rushton, A.W.A., Leng, M.J., and Gabbott, S., 2011. A refined chronology for the Cambrian succession of southern Britain. Journal of the Geological Society, London, v. 168, pp. 705-716.

Hughes, N.C., 2016. The Cambrian palaeontological record of the Indian subcontinent. Earth-Science Reviews, v. 159, pp. 428-451.

Hughes, N.C., and Jell, P.A., 1999. The biostratigraphy and biogeography of Himalayan Cambrian trilobites. In: Macfarlane, A., Sorkhabi, and R.B., Quade, J. (Eds.), Himalaya and Tibet: Mountain Roots to Mountain Tops. Geological Society of America Special Paper, v. 328, pp. 109-116.

Hughes, N.C., Myrow, P., Peng, S.C., and Banerjee, D. M., 2018. The Parahio Formation of the Tethyan Himalaya: the type section, thickness, lithostratigraphy and biostratigraphy of the best characterised Cambrian succession in the Indian Subcontinent. Journal of the Palaeontological Society of India, v. 63(1), pp. 1-18.

Jell, P. A., 1975. Australian Middle Cambrian eodiscoids with a review of the superfamily. Palaeontographica Abteilung A, v. 150, pp. 1-97.

Jell, P.A., and Hughes, N.C., 1997. Himalayan Cambrian trilobites. Special Papers in Palaeontology, v. 58, pp. 1-113.

Kobayashi, T., 1935. The Cambro-Ordovician formations and faunas of South Chosen. Palaeontology. Part III. Cambrian faunas of South Chosen with special study on the Cambrian trilobite genera and families. Journal of the Faculty of Science, Imperial University of Tokyo, section 2, v. 4, pp. 49-344.

Kobayashi, T., 1944. On the eodiscids. Journal of the Faculty of Science, Tokyo University, section 2, v. 7, pp. 1-74.
Korovnikov, I.V., 2001. Lower and Middle Cambrian boundary and trilobites from northeast Siberia Platform. Palaeoworld, v. 13, pp. 270-275.

Korovnikov, I.V., 2006. Lower and Middle Cambrian boundary in open shelf facies of Siberian Platform. Palaeoworld, v. 15, pp. 424-430.

Kruse, P.D., Laurie, J.R., and Webby, B.D., 2004. Cambrian geology and palaeontology of the Ord Basin. Memoirs of the Association of Australasian Palaeontologists, v. 30, pp. 1-58.

Kruse, P.D., Jago, J.B., and Laurie, J.R., 2009. Recent developments in Australian Cambrian biostratigraphy. Journal of Stratigraphy, v. 33(1), pp. 35-47.

Landing, E., 1994. Precambrian-Cambrian boundary global stratotype ratified and a new perspective of Cambrian time. Geology, v. 22(2), pp. 179-182.

Landing, E., Bowring, S.A., Davidek, K.L., Westrop, S.R., Geyer, G., and Heldmaier, W., 1998. Duration of the Cambrian: U-Pb ages of the volcanic ashes from Avalon and Gondwana. Canadian Journal of Earth Sciences, v. 35, pp. 329-338.

Landing, E, Peng, S, Babcock, L.E. Geyer, G., and Moczydlowska-Vidal, M., 2007. Global standard names for the lowermost Cambrian series and stage. Episodes, v. 30, pp. 287-289.

Laurie, J.R., 2004. Early Middle Cambrian trilobite faunas from NTGS Elkedra 3 corechole southern Georgina Basin, Northern Territory. Cambrian-Ordovician Studies I. Memoir of the Association of Australasian Palaeontologists, v. 30, pp. 221-260.

Laurie, J.R., 2016. Whitehouse's Redlichia (Trilobita) specimens from the Georgina Basin, Western Queensland. Australasian Palaeontological Memoirs, v. 49, pp. 75-82.

Lermontova, E.V., 1940. Arthropoda, Class Trilobita. In: Vologdin, A,G. (Ed.), Atlas of the leading forms of the fossil faunas of the U.S.S.R., 1, Cambrian, Gosgeolizdat. Moscow-Leningrad, 112-157.

Liñán, E., Perejón, A., Gonzalo, R., Moreno-Eiris, E., and Oliveira, J.T. de., 2004. The Cambrian System in Iberia. Publicaciones del Instituto Geológico y Minero de España, Series Cuadernos del Museo Geominero, v. 3, pp. 1-63.

Liñán, E., Dies Alvarez, M.E., Gámez Vintaned, J.A., Zhuravlev, A.Yu., Gozalo, R., Bauluz, B., Subias, I., Zamora, S., Chirivella Martorell, J.B., Mayoral, E., Gursky, H.J., Esteve, J., and Andrés, J.A., 2008. Proposed Global Stratotype Section and boundary Point (GSSP) for Cambrian System stage 5 and series 3 in Murero (Spain). In: Voroninoy (Ed.), XIII International Field Conference of the Cambrian Stage Subdivision Working Group. The Siberian Platform, Western Yakutia. Sibirskiy Nauchno-issledovat'skiy Institut Geologiy, Geofiziki i Mineral'nogo Syr'ya (SNIIGGIMS), Novosibirsk, pp. 43-48.

Loyd, S.J., Marenco, P.J., Hagadorn, J.W., Lyons, T.W., Kaufman, A.J., Sourtovar, F., and Corsetti, F.A., 2012. Sustained low marine sulfate concentrations from the Neoproterozoic to the Cambrian: insights from carbonates of northwestern Mexico and eastern California. Earth Planetary Science Letter, v. 339-340(4), pp. 79-94.

Lu, Y.H., 1950. On the genus Redlichia with description of its new species. Geological Review, v. 15, pp. 157-169.

Lu, Y.H., and Chien, Y.Y., 1964. Cambrian trilobites. In: Institute of Geology and Palaeontology, Academia Sinica (Ed.), A Handbook of Index Fossils of South China. Science Press, Beijing, pp. 26-39.

Lu, Y.H., Chang (Zhang), W.T., Chien, Y.Y., Chu (Zhu), C.L., Lin, H.L., Zhou, Z.Y., Qian, Y., Zhang, S.G., and Wu, H.J., 1974. Cambrian trilobites. In: Nanjing Institute of Geology and Palaeontology, Academia Sinica (Ed.), Handbook of Stratigraphy and Palaeontology, Southwest China. Science Press, Beijing, pp. 82-107.

Matthew, G.F., 1899, Studies on Cambrian faunas, no. 3: Upper Cambrian fauna of Mt. Stephen, British Columbia. Transactions of the Royal Society of Canada, Series 2, v. 5, pp. 39-66.

McCollum, L.B., and Sundberg, F.A., 2005. The use of Oryctocephalus indicus as a "Lower-Middle" Cambrian boundary GSSP: A status report. Acta Micropalaeontological Sinica, v. 22, pp. 113-114.

McCollum, L.B., and Sundberg, F.A., 2007. Cambrian trilobite biozona- 
tion of the Laurentian Delamaran Stage in the southern Great Basin, U.S.A.: Implications for global correlations and defining a Series 3 global boundary stratotype. Memoirs of the Association of Australasian Palaeontologists, v. 34, pp. 147-156.

Moczydłowska, M., 1991. Acritach biostratigraphy of Lower Cambrian and the Precambrian-Cambrian boundary in southeastern Poland. Fossils and Strata, v. 29, pp. 1-127.

Moczydłowska, M., 1998. Cambrian acritarchs from upper Silesia, Poland - biochnology and tectonic implications. Fossils and Strata, v. 46, pp. $1-121$.

Moczydłowska, M., 1999. The Lower-Middle Cambrian boundary recognized by acritarchs in Baltica and at the margin of Gondwana. Bolletino della Società Paleontologica Italiana, v. 38, pp. 207-225.

Moczydłowska, M., and Vidal,G., 1988. Early Cambrian acritarchs from Scandinavia and Poland. Palynology, v. 12, pp. 1-10.

Moczydłowska, M., and Yin, L.M., 2012. Phytoplanktic microfossils record in the lower Cambrian and their contribution to stage chronostratigraphy. In: Zhao, Y.L., Zhu, M.Y., Peng, J., Gaines, R.R., and Parsley, R.L. (Eds.), Cryogenian-Ediacaran to Cambrian Stratigraphy and Paleontology of Guizhou, China. Journal of Guizhou University (Natural Science), v. 29 (Supplement 1), pp. 49-58.

Montañez, I.P., Osleger, D.A., Banner, J.L., Mack, L.E., and Musgrove, M., 2000. Evolution of the $\mathrm{Sr}$ and $\mathrm{C}$ isotope composition of Cambrian oceans. GSA Today, v. 10(5), pp. 1-7.

Naimark, E.B., 2008. Morphogenesis in the Genus Peronopsis Hawle et Corda, 1847. Paleontological Journal, v. 42(4), pp. 53-64.

Öpik, A.A., 1970. Redlichia of the Ordian (Cambrian) of Northern Australia and New South Wales. Bulletin of the Bureau of Mineral Resources of Australia, v. 114, pp. 1-66.

Palacios, T., 2015. Acritarch assemblages from the Oville and Barrios Formations, northern Spain: a pilot proposal of a middle Cambrian (Series 3) acritarch biozonation in northwestern Gondwana. Review of Palaeobotany and Palynology, v. 219(3), pp. 71-105.

Palmer, A.R., 1998. A proposed nomenclature for stages and series for the Cambrian of Laurentia. Canadian Journal of Earth Sciences, v. 35, pp. 323-328

Palmer, A.R., and Repina, L.N., 1993. Through a glass darkly: taxonomy, phylogeny and biostratigraphy of the Olenellina. The University of Kansas Palaeontological Contribuition, New Series, v. 3, pp. 1-35.

Peng, J., Zhao, Y.L., Yuan, J.L., Yao, L., and Yang, H., 2009. Bathynotus: A key trilobite taxon for global stratigraphic boundary correlation between Cambrian Series 2 and Series 3. Progress in Natural Science, v. 19(1), pp. 99-105.

Peng, J., Yuan, J.L. Zhao, Y.L., Sun, H.J., Yang, X.L., and Yang, Y. N., 2014. The trilobite Bathynotus from the Cambrian Series 2 of China and its implications for global correlation. GFF, v. 136(1), pp. 203-207.

Peng, S.C., 2003. Chronostratigraphic subdivision of the Cambrian of China. Geologica Acta, v. 1(1), pp. 135-144.

Peng, S.C., 2004. Suggested global subdivision of Cambrian System and two potential GSSPs in Hunan, China for defining Cambrian stages. In: Choi, D.K. (Ed.), Korea 2004, Ninth International Conference of the Cambrian Stage Subdivision Working Group, Abstracts with program. The Paleontological Society of Korea, Taebaek, p. 25.

Peng, S.C., 2006. A new global framework with four series for Cambrian System. Journal of Stratigraphy, v. 30(2), pp. 147-148.

Peng, S.C., 2009. The newly developed Cambrian biostratigraphic succession and chronostratigraphic scheme for South China. Chinese Science Bulletin (English Edition), v. 54, pp. 4161-4179.

Peng, S.C., 2018. Cambrian. In: National Committee on Stratigraphy of China (Ed.), Explanation of the Stratigrapgic Chart of China (2014). Geological Press, Beijing, pp. 73-100.

Peng, S.C., and Babcock, L.E., 2001. Cambrian of the Hunan-Guizhou region, South China. Palaeoworld, v. 13, pp. 3-51.

Peng, S.C., and Robison, R.A., 2000. Agnostoid biostratigraphy across the Middle-Upper Cambrian boundary in China. Journal of Paleontology, v. 74, Memoir 53, pp. 1-104.

Peng, S.C., Yuan, J.L, and Zhao, Y.L., 2000. Taijiangian Stage: a new chronostratigraphical unit for the traditional Lower Middle Cambrian in South China. Journal of Stratigraphy, v. 24(1), pp. 53-54.

Peng, S.C., Babcock, L.E., Robison, R.A., Lin, H.L., Rees, M.N., and Saltzman, M.R., 2004a. Global Standard Stratotype-section and Point (GSSP) of the Furongian Series and Paibian Stage (Cambrian). Lethaia, v. 37(4), pp. 365-379.

Peng, S.C., Zhu, X.J., Babcock, L.E., and Wang, H.F., 2004b. Potential Global Stratotype Sections and Points in China for defining Cambrian stages and series. Geobios, v. 37(2), pp. 253-258.

Peng, S.C., Babcock, L.E., Geyer, G., and Moczydłowska, M., 2006. Nomenclature of Cambrian epochs and series based on GSSPs - Comments on an alternative proposal by Rowland and Hicks. Episodes, v. 29(2), pp. 130-132.

Peng, S.C., Babcock, L.E., Zuo, J.X., Lin, H.L., Zhu, X.J., Yang, X.F., Robison, R.A., Qi, Y.P., Bagnoli, G., and Chen, Y.A., 2009a. The Global boundary Stratotype Section and Point of the Guzhangian Stage (Cambrian) in the Wuling Mountains, northwestern Hunan, China. Episodes, v. 32(1), pp. 41-55.

Peng, S.C., Hughes, N.C., Heim, N.A., Sell, B. B., Zhu, X.J., Myrow, P.M., and Parcha, S.K., 2009b. Cambrian trilobites from the Parahio and Zanskar Valleys, Indian Himalaya. Lawrence (U.S.A.). Journal of Paleontology, Memoir 71, pp. 1-95.

Peng, S.C., Babcock, L E., Zuo, J.X., Lin, H.L., Zhou, C.M., Yang, X.F., Qi, Y.P., Bagnoli, G., Wang, L.W. 2012a. Global Standard Stratotypesection and Point (GSSP) for the base of the Jiangshanian Stage (Cambrian: Furongian) at Duibian, Jiangshan, Zhejiang, Southeast China. Episodes, v. 35(4), pp. 462-477.

Peng, S.C., Babcock, L.E., and Cooper, R.A., 2012b: The Cambrian Period. In: Gradstein, F.M., Ogg, J.G., Schmitz, M.D. and Ogg, G.M. (Eds.), The Geologic Time Scale 2012. Volume 2, Elsevier BV, Amsterdam, pp. 437-488.

Peng, S.C., Babcock, L.E., Zhu, X.J., Lei, Q.P., and Dai, T., 2017. Revision of the oryctocephalid trilobite genera Arthricocephalus Bergeron and Oryctocarella Tomashpolskaya and Karpinski (Cambrian) from South China and Siberia. Journal of Paleontology, v. 91(5), pp. 933-959

$\mathrm{Pu}$, X.C., and Ye, H.Z., 1991. Cambrian sedimentary facies and palaeogeography framework in southern China. Collected Papers of Lithofacies and Paleogeography, v. 6, pp. 1-16.

Reed, F.A., 1910. The Cambrian fossils of Spiti. Memoirs of Geological Survey of India, Palaeontologia India, v. 15, pp. 1-70.

Remane, J., Bassett, M.G., Cowie, J.W., Gohrbandt, K.H., Lane, H.R., Michelsen, O., and Wang, N.W., 1996. Revised guidelines for the establishment of global chronostratigraphic standards by the International Commission on Stratigraphy (ICS). Episodes, v. 19(3), pp. 77-81.

Robison, R.A., 1982. Some Middle Cambrian agnostoid trilobites from western North America. Journal of Paleontology, v. 56(1), pp. 132-160.

Robison, R.A. and Babcock, L.E., 2011. Systematics, paleobiology, and taphonomy of some exceptionally preserved trilobites from Cambrian Lagerstätten of Utah. Paleontological Contributions, v. 5, pp.1-47.

Rushton, A.W.A., 1966. The Cambrian trilobites from the Purley Shales of Warwickshire. Monograph of Palaeontographical Society of London, v. 120(511), pp. 1-55.

Saito, K., 1934. Older Cambrian trilobite and conchostraca from northwestern Korea. Japanese Journal of Geology and Geography, v. 11, pp. 211-237.

Schmitz, M. D., 2012. Radiogenic isotopes geochronology. In: Gradstein, F. M, Ogg, J. G., and Schmith, M. D., and Ogg, G. M. (Eds.), The Geologic Time Scale 2012, Elsevier BV, Amsterdam, pp. 115-126.

Shabanov, Yu.Ya., Korovnikov, I.V., Pereladov, V.S., and Fefelov, A.F., 2008. Excursion 1a. The traditional Lower-Middle Cambrian boundary in the Kuonamka Formation of the Molodo River section (the southeastern slope of the Olenek Uplift of the Siberian Platform) proposed as a candidate for GSSP of the lower boundary of the Middle Cambrian and 
its basal (Molodian) stage, defined by the FAD of Ovatoryctocara granulata. In: Rozanov, A.Yu, and Varlamoov, A.I. (Eds.), The Cambrian System of the Siberian Platform. Part 2: North-East of the Siberian Platform, XIII International Field Conference of the Cambrian Stage Subdivision Working Group. PIN, RAS, Moscow and Novosibirsk, pp. 8-59.

Shergold, J.H., 1969. Oryctocephalidae (Trilobita: Middle Cambrian) of Australia. Bulletin of the Bureau of Mineral Resources of Australia, v. 104, pp. 1-66.

Shergold, J.H., and Geyer, G., 2001. The International Subcommission on Cambrian Stratigraphy: progress report. Acta Palaeontoloica Sinica, v. 40, pp. 1-3.

Shergold, J.H. and Geyer, G. 2003. Newsletter 2003. International Subcommission of Cambrian Stratigraphy) International Subcommission on Cambrian Stratigraphy, Würzburg, 12 p.

Shergold, J.H., and Whittington, H.B., 2000. The Cambrian trilobite Bathynotus (?Redlichioidea) in the northern Territory, Australia. Alcheringa, v. 24(1-2), pp. 1-10.

Singh, B.P., Virmani, N., Bhargava, O.N., Negia, R.S., Kishore, N., and Gill, A., 2016. Trilobite fauna of basal Cambrian Series 3 (Stage 5) from the Parahio Valley (Spiti), Northwest Himalaya, India and its biostratigraphic significance. Annales de Paléontologie, v. 102(1), pp. 59-67.

Sundberg, F.A., 2011. Delamaran biostratigraphy and lithostratigraphy of southern Nevada. In: Hollingsworth, J.S., Sundberg, F.A. and Foster, J.R. (Eds.), Cambrian stratigraphy and Paleontology of Northern Arizona and Southern Nevada. International Subcommission on Cambrian Stratigraphy. Museum of Northern Arizona Bulletin, v. 67. pp. 174-185.

Sundberg, F.A., and McCollum, L.B., 1997. Oryctocephalids (Corynexochida: Trilobita) of the Lower-Middle Cambrian boundary interval from California and Nevada. Journal of Palaeontology, v. 71(6), pp. 1065-1090.

Sundberg, F.A., and McCollum, L.B., 2003. Early and Middle Cambrian trilobites from the outer-shelf deposits of Nevada and California, USA. Palaeontology, v. 46, pp. 945-986.

Sundberg, F.A., Yuan, J.L., McCollum, L.B., and Zhao, Y.L., 1999. Correlation of Lower-Middle Cambrian boundary of South China and Western United States of America. Acta Palaeontoloica Sinica, v. 38 (supplement), pp. 102-107.

Sundberg, F.A., Zhao, Y.L., Yuan, J.L., and Lin, J.P., 2010. Summary of recent quarrying across the proposed GSSP for Stage 5 (Cambrian) at the Wuliu-Zengjiayan section, Guizhou, China. Journal of Stratigraphy, v. 34(2), pp. 289-292.

Sundberg, F.A., Zhao, Y.L., Yuan, J.L., and Lin, J.P., 2011. Detailed trilobite biostratigraphy across the proposed GSSP for Stage 5 ("Middle Cambrian" boundary) at the Wuliu-Zengjiayan section, Guizhou, China. Bulletin of Geosciences, v. 86(3), pp. 423-464.

Sundberg, F.A., Geyer, G., Kruse, P.D., McCollum, L.B., Pegel, T.V., Zylińska, A., and Zhuralev, A.Yu., 2016. International correlation of the Cambrian Series 2-3, Stage 4-5 boundary interval. Memoirs of the Association of Australasian Palaeontologists, v. 49, pp. 83-125.

Tchernysheva, N.Ye., 1962. Cambrian trilobites of the Family Oryctocephalidae. In: Shvedov, N.A. (Ed.), Problems of oil and gas occurrence in the Soviet Arctic, Palaeontology and Biostratigraphy, 3. Trudy Nauchno-Issledovatelskogo Instituta Geologii Arktiki, v. 127, pp. 3-52.

Volkova, N.A., 1990. Middle and Upper Cambrian acritarchs in the East European Platform. Trudy Akademia Nauk SSSR, Geologicheskii Institut, v. 454, pp. 1-116.

Walcott, C.D., 1912. Cambrian geology and paleontology Il;Middle Cambrian Branchiopode, Malocrastraca, Trilobita, and Merostomata. Smithsonian Miscellaneous Collections, v. 57, pp. 145-228.

Wang, C.J., Zhao, Y.L., Peng, J., Yang, X.L., Bai, J., Liu, Y., and Chen, T., 2014. Biomarker evidence for biotic and environmental change across the Cambrian Series 2-Series 3 boundary at the Wuliu-Zengjiayan section, Guizhou, China. Science China: Earth Science, v. 57(11), pp. 2781-2790.

Wang, M.K., Zhao, Y.L., Luo, X.C., and Chen, W.Y., 2016. Olenoides Meek, 1877 from the "Tsinghsutung Formation" at Balang, Jianhe County, Guizhou Province. Geological Journal of China Universities, v. 22(3), pp. 486-493. (in Chinese with English abstract).

Wang, Y. (Ed.), 1964. Handbook of index fossils of South China. Science Press, Beijing, 173 p.

Wang, Y., Yu, Y.Y., Peng, J., and Wang, P.L., 2006. Discussion on the sequence stratigraphy and sea-level changes of the Kaili Formation at Balang, Jianhe, Guizhou. Journal of Stratigraphy, v. 30(1), pp. 34-42.

Webster, M., 2009. Systematic revision of the Cambrian trilobite Bathynotus Hall, 1860, with documentation of new occurrences in western Laurentia and implications for intercontinental biostratigraphic correlation. Memoirs of the Association of Australasian Palaeontologists, v. 37, pp. 369-406.

Weidner, T., and Ebbestad, J.O., 2014. The early Middle Cambrian agnostid Pentagnostus praecurrens (Westergård, 1936) from Sweden. Memoirs of the Association of Australasian Palaeontologists, v. 45, pp. 403 419.

Westergård, A.H., 1946. Agnostidea of the Middle Cambrian of Sweden. Sveriges Geologiska Undersökning, Series C, v. 477, pp. 1-140.

Whittington, H.B., 1988. Hypostomes and ventral cephalic sutures in Cambrian trilobites. Palaeontology, v. 31(3), pp. 577-609.

Whittington, H.B., 1994. Burlingiids: Small proparian Cambrian trilobites of enigmatic origin. Palaeontology, v. 37, pp. 1-16.

Whittington, H.B., 1995. Oryctocephalid trilobites from the Cambrian of North America. Palaeontology, v. 38, pp. 543-562.

Wotte, T., Strauss, H., and Sundberg, F.A., 2011. Carbon and sulfur isotopes from the Cambrian Series 2-Cambrian Series 3 of Laurentia and Siberia. In: Hollingsworth, J.S., Sundberg, F.A. and Foster, J.R. (Eds.), Cambrian stratigraphy and Paleontology of Northern Arizona and Southern Nevada. International Subcommission on Cambrian Stratigraphy. Museum of Northern Arizona Bulletin, v. 67. pp. 43.

Wotte, T., Strauss, H., Fugmann, A., and Garbe-Schönberg, D., 2012. Paired $\delta^{34} \mathrm{~S}$ data from carbonate-associated sulfate and chromium-reducible sulfur across the traditional Lower-Middle Cambrian boundary of WGondwana. Geochimica et Cosmochimica Acta, v. 85, pp. 228-253.

Yang, R.D., and Yin, L.M., 2001. Acritarch assemblages from the EarlyMiddle Cambrian Kaili Formation of East Guizhou Province and biostratigraphic implication. Acta Micropalaeontologica Sinica, v. 18, pp. 55-69.

Yang, R.D., Zhu, L.J., and Wang, S.J., 2003. Negative carbon isotopic excursion on the Lower/Middle Cambrian boundary of Kaili Formation, Taijiang County, Guizhou Province, China: Implications for mass extinction and stratigraphic division and correlation. Science in China (Series D), v. 46(9), pp. 872-881.

Yang, X.L., Zhao, Y.L., Babcock, L.E., and Peng, J., 2017. Siliceous spicules in a vauxiid sponge (Demospongia) from the Kaili Biota (Cambrian Stage 5), Guizhou, South China. Scientific Reports, v. 7, 42945, DOI: $10.1038 /$ srep42945.

Yang, Y.N., Zhao, Y.L., and Zhang, X.L., 2016. Fossil priapulid Ottoia from the Kaili biota (Cambrian Series 3) of South China. Journal of Systematic Palaeontology, v. 14 (6), pp. 527-543.

Yao, L., Peng, J, Fu, X.P. and Zhao, Y.L., 2009. Ontogenesisof tuzoia bispinosa (arthropoda) from the Middle Cambrian Kaili Biota, Guizhou, China. Acta Palaeontoloica Sinica, v. 48(1), pp. 56-64.

Yin, G.Z., 1987. Cambrian. In: Bureau of Guizhou Geology and Mineral Resources (Ed.), Regional Geology of Guizhou Province. PRC Ministry of Geology and Mineral Resources: Geological Memories series 1, v. 7, Geological Publishing Press, Beijing, pp. 49-96.

Yin, L.M., and Yang, R.D., 1999. Early-Middle Cambrian acritarchs in the Kaili Formation from Taijiang County, Guizhou, China. Acta Palaeontologica Sinica, v. 38 (Supplement), pp. 66-78.

Yin, L.M., Zhao, Y.L., Yang, R.D., and Peng, J., 2010. Acritarchs from the Early-Middle Cambrian Kaili Formation in the Wuliu-Zengjiaya Section, east Guizhou Province, China. Acta Palaeontoloica Sinica, v. 49(2), pp. 164-173.

Yin, L.M., Yang, R.D., Peng, J., and Kong, F.F., 2009. New data regarding acritarch biostratigraphy from the Early-Middle Cambrian Kaili For- 
mation in Chuandong, Guizhou Province, China. Progress in Natural Science, v. 19(1), pp. 107-114.

Yin, L.M., Zhao, Y.L., Bian, L.Z., and Peng, J., 2013. Comparison between cryptospores from the Cambrian Log Cabin Member, Pioche Shale, Nevada, USA and similar specimens from the Cambrian Kaili Formation, Guizhou, China. Science China, v. 56(5), pp. 703-709.

Yin, L.M., Wang, C.J., Zhao, Y.L., and Ou, Z.J., 2016. Early-Middle Cambrian palynomorph microfossils and related geochemical events in South China. Journal of Earth Sciences, v. 27(2), pp. 180-186.

Yuan, J.L., and Esteve, J., 2015. The earliest species of Burlingia Walcott, 1908 (Trilobta) from South China - biostratigraphical and palaeogeographical significance. Geological Magazine, v. 152(2), pp. 358-366.

Yuan, J.L., and Ng, T.W., 2014. Tentative correlation of the Duyunian (Cambrian Series 2, Stage 4) and the Taijiangian (Cambrian Series 3, Stage 5) between South China and the Mediterranean region. GFF, v. 136(1), pp. 314-319.

Yuan, J.L and Zhao, Y.L., 1999. Tuzoia (bivalved arthropods) from the lower- middle Cambrian Kaili Formation of Taijiang, Guizhou. Acta Palaeontologica Sinica. v. 38(Supplement), pp. 88-94

Yuan, J.L., Zhao, Y.L., Wang, Z.Z., Zhou, Z.Y., and Cheng, X.Y., 1997. A preliminary study on Lower-Middle Cambrian boundary and trilobite fauna at Balang, Taijiang, Guizhou, South China. Acta Palaeontologica. Sinica, v. 36(4), pp. 494-524.

Yuan, J.L., Zhao, Y.L., and Guo, Q.J., 1999. On the Kaili Formation. Acta Palaeontologica Sinica, v. 38 (supplement), pp. 15-27.

Yuan, J.L., Zhao, Y.L., Li, Y., and Huang, Y.Z., 2002. Trilobite Fauna of the Kaili Formation (uppermost Lower Cambrian-lower Middle Cambrian) from southeastern Guizhou, South China. Shanghai Science and Technology Press, Shanghai, $423 \mathrm{p}$.

Zhang, W.T., Lu, Y.H., Zhu, Z.L., Qian, Y.Y., Lin, H.L., Zhou, Z.Y., and Yuan, J.L., 1980. Cambrian trilobite faunas of southwestern China. Palaeontologica Sinica, Series B, 159. Science Press, Beijing, 497 p.

Zhang, Z.H., Shen, J.W., Gong, X.Y., Zhao, Y.L., Mao, J.R., and Yan, C.H., 1996. A preliminary discussion on preservation condition of Kaili Fauna, Middle Cambrian, Taijiang, Guizhou. Acta Palaeontologica Sinica. v. 35(5), pp. 607-622.

Zhao, Y.L. and Zhu, M.Y., 1994. Medusiform fossils of Kaili Fauna fromTaijing, Guizhou. Acta Palaeontology Sinica, v. 33(3), pp. 272-280.

Zhao, Y.L., Huang, Y.Z., and Gong, X.Y., 1994. Echinoderm fossils of Kaili fauna from Taijiang, Guizhou. Acta Palaeontologica Sinica, v. 33(3), pp. 305-324.

Zhao, Y.L., Qian, Y., and Li X.S., 1994. Wiwaxia from Early-Middle Cambrian Kaili Formation in Taijiang, Guizhou. Acta Palaeontologica Sinica, v. 33(3), pp. 359-366.

Zhou, Z.Y., Yuan, J.L., Zhang, Z.H., Wu, X.R., and Yin, G.Z., 1980. Division and correlation of Cambrian stratigraphy in Guizhou Province, China. Journal of Stratigraphy, v. 4(4), pp. 273-281.

Zhao, Y.L., Yang, R.D., Yuan, J.L., Zhu, M.Y., Guo, Q.J., Yang, X.L., and Tai, T.S., 2001a. Cambrian stratigraphy at Balang, Guizhou Province, China: Candidate section for a global unnamed series and stratotype section for the Taijiangian Stage. Palaeoworld, v. 13, pp. 189-208.

Zhao, Y.L., Yuan, J.L., and McCollum, L.B., 2001b. A potential GSSP for the Lower and Middle Cambrian boundary near Balang Village, Taijiang County, Guizhou Province, China. Acta Paleontologica Sinica, v. 40, pp. $130-142$

Zhao, Y.L., Yuan, J.L., Peng, S.C., Guo, Q.J., Zhu, L.J., Peng, J., and Wang, P.L., 2004. Proposal and prospects for the global Lower-Middle Cambrian boundary. Progress in Natural Science, v. 14(12), pp. 10341039.

Zhao, Y.L., Zhu, M.Y., Babcock, L.E., Yuan, J.L., Parsely, R.L., Peng, J., Yang, X.L., and Wang, Y., 2005. Kaili Biota: A taphonomic window on diversification of metazoans from the basal Middle Cambrian: Guizhou,
China. Acta Geologica Sinica, v. 79(6), pp. 751-765

Zhao, Y.L., Yuan, J.L., Peng, S.C., Yang, X.L., Peng, J., Lin, J.P., and Guo, Q.J., 2006. A restudy of Oryctocephalus indicus (Reed, 1910). Progress in Natural Science, v. 16(11), pp. 1177-1182.

Zhao, Y.L., Yuan, J.L., Peng, S.C., Babcock, L.E., Peng, J., Lin, J.P., Guo, Q.J., and Wang,Y.X., 2007. New data on the Wuliu-Zengjiayan section (Balang, South China), GSSP candidate for the base of Cambrian Series 3. Memoirs of the Association of Australasian Palaeontologists, v. 33, pp. $57-65$.

Zhao, Y.L., Yuan, J.L., Peng, S.C., Babcock, L.E., Peng, J., Guo, Q.J., Lin, J.P., Tai, T.S., Yang, R.D., and Wang, Y.X., 2008. A new section of Kaili Formation (Cambrian) and a biostratigraphic study of the boundary interval across the undefined Cambrian Series 2 and Series 3 at Jianshan, Chuandong Village, Jianhe County, China with a discussion of global correlation based on the first appearance datum of Oryctocephalus indicus (Reed, 1910). Progress in Natural Science, v. 18, pp. 1549-1556.

Zhao, Y.L., Zhu, M.Y., Babcock, L.E., and Peng, J., (eds.). 2011. The Kaili Biota-Marine organisms from 508 million years ago. Guiyang, Guizhou Science and Technology Press, $247 \mathrm{p}$.

Zhao, Y.L., Peng, J., Yuan, J.L., Babcock, L.E, Guo, Q.J., Yin, L.M., Yang, X.L., Tai, T.S., Wang, C.J., Lin, J.P., Gaines, R.R, Sun, H.J., and Yang, Y.N., 2012a. Discussion on the Global Standard Stratotype Section and Point (GSSP) for defining the conterminous base of Cambrian provisional Series 3 and Stage 5. In: Zhao, Y.L., Zhu, M.Y., Peng, J., Gaines, R.R., and Parsley, R.L. (Eds.), Cryogenian-Ediacaran to Cambrian Stratigraphy and Paleontology of Guizhou, China. Journal of Guizhou University (Natural Science), v. 29 (Supplement 1), pp. 35-48.

Zhao, Y.L., Yang, Y.N., Peng, J., Yuan, J.L., Sun, H.J., Yan, X., and Zhang, P.X., 2012b. The Kaili Formation and Kaili Biota at the Sanwan Section in Guizhou Province, China and boundary between Cambrian Series 2/Series 3. In: Zhao, Y.L., Zhu, M.Y., Peng, J., Gaines, R.R., and Parsley, R.L. (Eds.), Cryogenian-Ediacaran to Cambrian Stratigraphy and Paleontology of Guizhou, China. Journal of Guizhou University (Natural Science), 29 (Supplement 1), 77-88.

Zhao, Y.L., Peng, J., Yuan, J.L., Guo, Q.J., Tai, T.S., Yin, L.M., Parsley, R.L., Yang, Y.N., Yang, X.L., and Zhang, P.X. 2012c. The Kaili Formation and Kaili Biota at the Wuliu-Zengjiayan Section of Guizhou Province, China and proposed Global Standard Stratotype section and Point (GSSP) of the unnamed Cambrian Series 3, Stage 5. In: Zhao, Y.L., Zhu, M.Y., Peng, J., Gaines, R.R., and Parsley, R.L. (Eds.), CryogenianEdiacaran to Cambrian Stratigraphy and Paleontology of Guizhou, China. Journal of Guizhou University (Natural Science), 29(Supplement 1), 108-124.

Zhao, Y.L., Yuan, J.L., Guo, Q.J., Peng, J., Yin, L.M., Yang, X.L., Wang, C.J., and Sun, H.J., 2014. Comments on some important issues concerning the establishment of a GSSP for Cambrian Stage 5. GFF, v. 136(1), pp. 333-336.

Zhao, Y.L., Yuan, J.L., Peng, J., Yang, X.L., and Esteve, J., 2015. Restudy of Ovatoryctocara Tchernysheva, 1962 from the Kaili Formation, Jianhe County, Guizhou, South China. Annales de Paléontologie, v. 101(3), pp. 193-198.

Zhao, Y.L., Yuan, J.L., Esteve, J., and Peng, J., 2017. The oryctocephalid trilobite zonation across the Cambrian Series 2-Series 3 boundary at Balang, South China: a reappraisal. Lethaia, v. 50, pp. 400-406.

Zhu, M.Y., Erdtmann, B.D., and Zhao, Y.L., 1999. Taphonomy and paleoecology of the early Middle Cambrian Kaili Lagerstätte in Guizhou, China. Acta Palaeontologica Sinica, v. 38 (Supplement 1), pp. 28-57.

Zhu, M.Y., Zhang, J.M., Li, G.X., and Yang, A.H., 2004. Evolution of C isotopes in the Cambrian of China: implications for Cambrian subdivision and trilobite mass extinctions. Geobios, v. 37(2), pp. 287-301. 


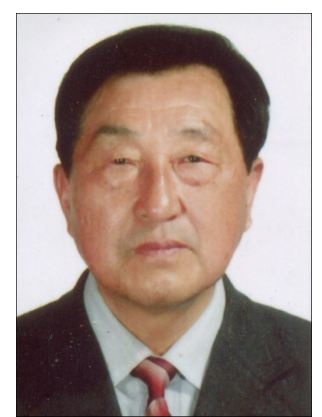

Zhao Yuanlong is a Professor at Guizhou Research Center of Palaeontology and College of Resources and Environment Engineering, Guizhou University. He has been working on Cambrian trilobites, chronostratigraphy of Cambrian Series 3 and Stage 5, and early metazoan paleobiology since 1961 .

As one of primary researchers, he found the Cambrian soft-bodied Kaili Biota with his colleagues. Currently he focuses his research mainly on defining provisional Cambrian Stage 4, and the taxonomy and biostratigraphy of oryctocephalid trilobites.

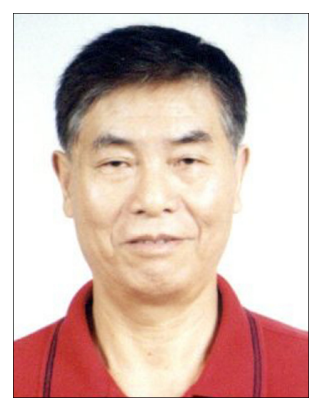

Jinliang Yuan is a Research Professor at the Nanjing Institute of Geology and Palaeontology, Chinese Academy of Sciences. He has been working on Cambrian biostratigraphy and trilobites, and Devonian, Carboniferous, and Permian trilobites since 1975. Recently he focuses on his research on Cambrian boundaries between Series 2 and the Miaolingian Series in South China and between Miaolingian and Furongian Series in North China, and on biostratigraphy and phylogeny of Cambrian oryctocephalid trilobites.

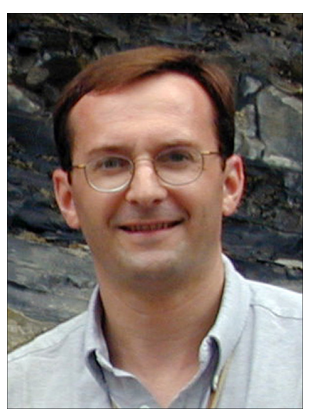

Loren E. Babcock is a Professor in the School of Earth Sciences at the Ohio State University, Columbus, Ohio, USA. His research interests are centered around trilobite paleobiology, taphonomy, and stratigraphy. In recent years, Babcock has focused attention on development of a global chronostratigraphic subdivision of the Cambrian System. He is currently Chairman of the International Subcommission on Cambrian Stratigraphy from 2012.

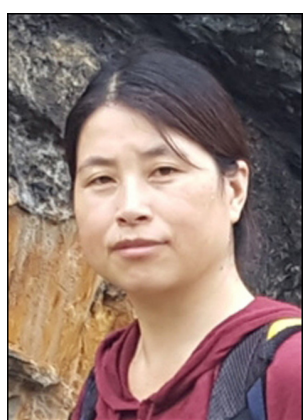

Xinglian Yang is a Professor at the Research Center of Palaeontology and College of Resource and Environment Engineering at Guizhou University, Guiyang, Guizhou, China. She has been working on Cambrian Stratigraphy and Palaeontology since 1999. Her research interests are mainly focused on early metazoan paleobiology and Cambrian stratigraphy, especially on the Cambrian sponges and chronostratigraphy of the boundary interval of Cambrian provisional Series 2 and Miaolingian Series in South China. 